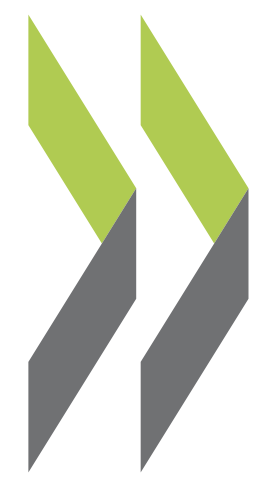

OECD Economics Department Working Papers No. 1422

Sustaining nature-based

Douglas Sutherland,

tourism in Iceland

Jane Stacey

https://dx.doi.org/10.1787/f28250d9-en 
Organisation de Coopération et de Développement Économiques

Organisation for Economic Co-operation and Development

09-Oct-2017

ECONOMICS DEPARTMENT

English - Or. English

\section{SUSTAINING NATURE-BASED TOURISM IN ICELAND}

ECONOMICS DEPARTMENT WORKING PAPERS No. 1422

By Douglas Sutherland and Jane Stacey

OECD Working Papers should not be reported as representing the official views of the OECD or of its member countries. The opinions expressed and arguments employed are those of the author(s).

Authorized for publication by Alvaro Pereira, Director, Country Studies Branch, Economics Department.

All Economics Department Working Papers are available at www.oecd.org/eco/workingpapers.

JT03420308

This document, as well as any data and map included herein, are without prejudice to the status of or sovereignty over any territory, to the delimitation of international frontiers and boundaries and to the name of any territory, city or area. 
ECO Working Papers should not be reported as representing the official views of the OECD or of its member countries. The opinions expressed and arguments employed are those of the author(s).

Working Papers describe preliminary results or research in progress by the author(s) and are published to stimulate discussion on a broad range of issues on which the OECD works.

Comments on Working Papers are welcomed, and may be sent to OECD Economics Department, 2 rue André-Pascal, 75775 Paris Cedex 16, France, or by e-mail to eco.contact@ oecd.org.

All Economics Department Working Papers are available at www.oecd.org/eco/workingpapers

This document, a well as any data and map included herein, are without prejudice to the status of or sovereignty over any territory, to the delimitation of international frontiers and boundaries and to the name of any territory, city or area.

The statistical data for Israel are supplied by and under the responsibility of the relevant Israeli authorities. The use of such data by the OECD is without prejudice to the status of the Golan Heights, East Jerusalem and Israeli settlements in the West Bank under the terms of international law.

\section{OECD (2017)}

You can copy, download or print OECD content for your own use, and you can include excerpts from OECD publications, databases and multimedia products in your own documents, presentations, blogs, websites and teaching materials, provided that suitable acknowledgment of OECD as source and copyright owner is given. All requests for commercial use and translation rights should be submitted to rights@oecd.org 


\section{Abstract/résumé \\ Sustaining nature-based tourism in Iceland}

Iceland has been experiencing a tourism boom. The number of tourists visiting annually quadrupled between 2010 and 2016 and shows continued strength. The tourism sector is now the major export earner and is also creating new jobs and supporting new businesses. The government budget has also benefitted from high tax revenues. The surge in tourism supported growth after the crisis and the sector has become a major pillar of the economy. But, the breakneck growth of tourism has created a number of challenges. Growing pains have emerged as accommodation supply has lagged in the wake of unexpectedly large number of tourists, contributing to pressure on the local housing market. The environment, particularly in some popular sites, has also come under pressure. The government has reacted to these environmental and social impacts and has worked with the industry to agree on a path forward. Sustaining a nature-based tourism for Iceland will require more coordinated policy across government and a long-term strategic plan that builds on Iceland's strengths. Protecting the unique environmental attractions of Iceland - while mitigating adverse social impacts - will lay the basis for the healthy development of a new important sector.

This working paper relates to the 2017 OECD Economic Survey of Iceland (http://www.oecd.org/eco/surveys/economic-survey-iceland.htm).

JEL classification: F64, O44, Q56, R31, Z32, Z38

Keywords: Tourism, environment, housing, growth, sustainable development

$* * * * *$

\section{Assurer la pérennité du tourisme de nature en Islande}

En Islande, le tourisme connaît un formidable essor. Le nombre de touristes visitant le pays chaque année a quadruplé entre 2010 et 2016 et tout indique que ce dynamisme va se poursuivre. De fait, le secteur du tourisme, qui est aujourd'hui la principale source de recettes d'exportations, crée également des emplois et voit se multiplier les créations d'entreprises. Le budget de l'Etat bénéficie par ailleurs d'une augmentation des recettes fiscales. Le développement du tourisme a permis d'étayer la croissance après la crise, et ce secteur est devenu l'un des principaux piliers de l'économie. Cela étant, la croissance vertigineuse du tourisme est aussi source de plusieurs difficultés. L'offre d'hébergements n'a pas suivi l'augmentation inattendue du nombre de touristes, ce qui est source de problèmes croissants et crée des pressions sur le marché local du logement. L'environnement, particulièrement dans certains sites populaires, est également mis à rude épreuve. Pour réagir à cet impact social et environnemental, les pouvoirs publics ont travaillé en collaboration avec les professionnels du secteur pour convenir d'une trajectoire pour l'avenir. Assurer la pérennité d'un tourisme de nature en Islande nécessitera de mieux coordonner l'action publique entre les différentes entités de l'État et d'arrêter un plan stratégique à long terme misant sur les atouts du pays. Protéger les richesses environnementales uniques de l'Islande tout en minimisant les conséquences sociales négatives permettra de jeter les base d'un développement sain dans un nouveau secteur d'activité important

Ce Document de travail se rapporte à l'Étude économique de l'OCDE de Islande 2017 (http://www.oecd.org/fr/eco/etudes/etude-economique-islande.htm).

Classification JEL: F64, O44, Q56, R31, Z32, Z38

Mots clés : Tourisme, environnement, loogement, croissanse, development durable 


\section{TABLE OF CONTENTS}

$\begin{array}{ll}\text { Iceland's tourism boom } & 7\end{array}$

Tourist arrivals and demand $\quad 7$

Tourism is highly dependent on nature $\quad 9$

The impact on the economy 11

Employment and business sector dynamism $\quad 14$

The impact on public finances $\quad 17$

Ensuring tourism is sustainable and inclusive 19

Developing nature-based tourism while managing the effects on the environment 19

Mitigating the social impacts of tourism $\quad 24$

Boosting productivity $\quad 27$

The policy framework has been evolving $\quad 31$

Ensuring consistency in tourism and transport policy $\quad 34$

Setting the path forward $\quad 35$

REFERENCES

\section{Figures}

1. International tourist numbers have risen dramatically 6

2. Tourism has taken off since $2010 \quad 7$

3. International visitors are becoming more diversified and mainly stay overnight $\quad 8$

4. International travel at Keflavik is highly seasonal $\quad 9$

$\begin{array}{ll}\text { 5. Most visitors come to experience nature } & 10\end{array}$

6. Iceland is a reasonably competitive tourism destination $\quad 11$

7. Tourism is now a major export earner $\quad 12$

8. The króna has appreciated strongly since 2013

9. Tourism represents a sizeable share of GDP and employment 13

10. Immigration is rising strongly, though many continue to leave. 14

11. Employment and firm creation in tourism services is growing robustly 15

12. New accommodation is being added, but occupancy rates keep rising 16

13. The exchange rate has begun to appreciate, unwinding some of the depreciation after the crisis 17

14. VAT revenue base broadening and rate narrowing had visible impacts 18

15. Maximising the number of tourists is not the best strategy 20

16. Arrivals of cruise line passengers is rising 23

17. Private accommodation accounts for a rising share of overnight stays 25

18. Rents are high 25

19. House prices are picking up and residential investment is beginning to respond 27

20. Employment growth is not strongly linked to gains in output per worker 28

21. Unemployment rates for people with tertiary education have been slower in coming down $\quad 29$

22. Reallocation on average has had little impact on wage gains 30

\section{Boxes}

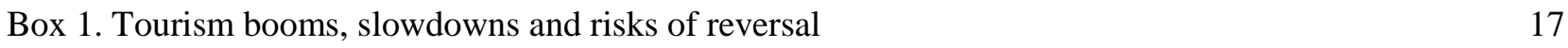

Box 2. Tourist numbers and the environment 20 
Box 3. Environmental certification

Box 4. Private short-term rentals and the sharing economy

Box 5. Statistics and research to support decision making 


\title{
SUSTAINING NATURE-BASED TOURISM IN ICELAND
}

\author{
By Douglas Sutherland and Jane Stacey ${ }^{1}$
}

Iceland is experiencing a tourism boom, with international tourist numbers growing annually by above $30 \%$ in recent years. Tourist numbers have quadrupled between 2010 and 2016 and the tourist season has become longer, particularly in the south west of the country (Figure 1). The surge in tourism has boosted the economy and helped to unwind some of the impacts of the financial crisis. New jobs have been created and foreign currency earnings have risen - easing financing constraints on the balance of payments - while the boost to tax revenues has contributed to improved public finances. The emergence of a new major sector of the economy is welcome and greater diversity will help insulate the economy from idiosyncratic shocks to which it is prone. Tourism creates new opportunities for businesses and employment as it continues to benefit from growing interest in nature-based tourism.

The rapid growth in tourism nevertheless came as a surprise and has created a number of growing pains. The capacity of the country to cope with the numbers now arriving is being stretched and public policy, infrastructure and business are beginning to catch up. Notably, investment in accommodation and infrastructure has fallen behind demand, creating a number of social and environmental strains which will eventually dissipate as investment comes on stream. Pubic services - such as health, emergency and policing - are under strain from increased number of users, and economic and tax policy have not fully adjusted to the changed structure of the economy.

The government has reacted by creating a task force, bringing together the Ministers responsible for tourism, finance, interior and environment, and charged with implementing a Road Map, which prioritises several policy areas. Working with local authorities and industries, the task force seeks to improve skills and quality in the tourism sector as well as study the consequences of tourism on nature conservation. This provides a basis to manage the development of tourism more effectively.

Figure 1. International tourist numbers have risen dramatically

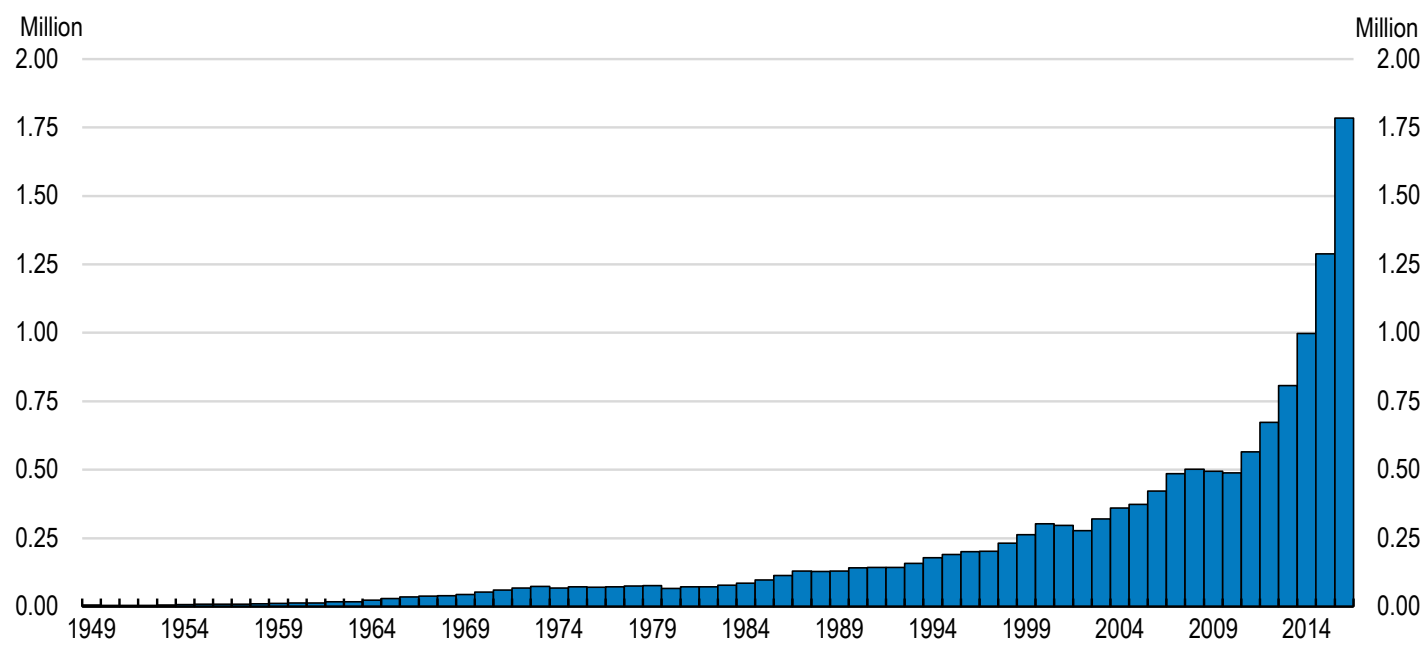

Source: Icelandic Tourist Board.

1. Douglas Sutherland (OECD/Economics Department) and Jane Stacey (OECD/Centre for Enrepreneurship, SMEs, Local Department). The authors would like to thank Alain Dupeyras (OECD/Centre for Enrepreneurship, SMEs, Local Department), Patrick Lenain, Alvaro Pereira, Urban Sila (OECD/Economics Department) and Icelandic officials for valuable comments. Special thanks are due to Damien Azzopardi for research and Brigitte Beyeler (both OECD/Economics Department) for technical preparation. 
The rest of the document considers recent developments in tourist arrivals and the impact on the economy before considering the interactions with environmental and social policy objectives. The last section addresses policy making and the choices the Icelandic authorities face in developing the sector for the future. The central challenge is to maximise long-term benefits derived from Iceland's unique natural environment while preserving these attractions and ensuring that the gains are shared across the population and with future generations. Iceland's attraction is largely the unspoilt character of its nature. Ensuring sustainability will therefore be important in preserving Iceland as an attractive nature-based tourist destination. The policy framework should build on the success of the fishing sector, targeting greater returns for Iceland than the development of the metallurgy sector and avoiding the boom and bust of the banking sector.

\section{Iceland's tourism boom}

Tourism has been growing rapidly internationally, rising on average by around $4 \%$ annually since the mid-1990s (Figure 2). In Iceland, tourist numbers were already growing somewhat faster on average than global growth (almost 7\%) before the late 2000s. However, after 2010, the numbers of international visitors began to grow at substantially faster rates, averaging around 25\% annually. In 2016, around 1.8 million international visitors arrived, four times more than in 2010. The beginning of the tourism boom, partly reflecting increasing appetite to visit more remote locations, was accompanied by Iceland making the headlines internationally with the 2008 financial market crash , the eruption of Eyjafjallajokull volcano in 2010 and the launch of the "Inspired by Iceland" campaign (PKF, 2013). Heightened awareness combined with the sharp depreciation of the króna in 2008, a fall in energy prices that lowered airline ticket prices and the entry of low-cost carriers to the market helped make Iceland an increasingly attractive tourism destination. The main international airport at Keflavik provided an important gateway with sufficient capacity to allow tourism to flourish.

\section{Figure 2. Tourism has taken off since $\mathbf{2 0 1 0}$}

Annual growth rate of international arrivals

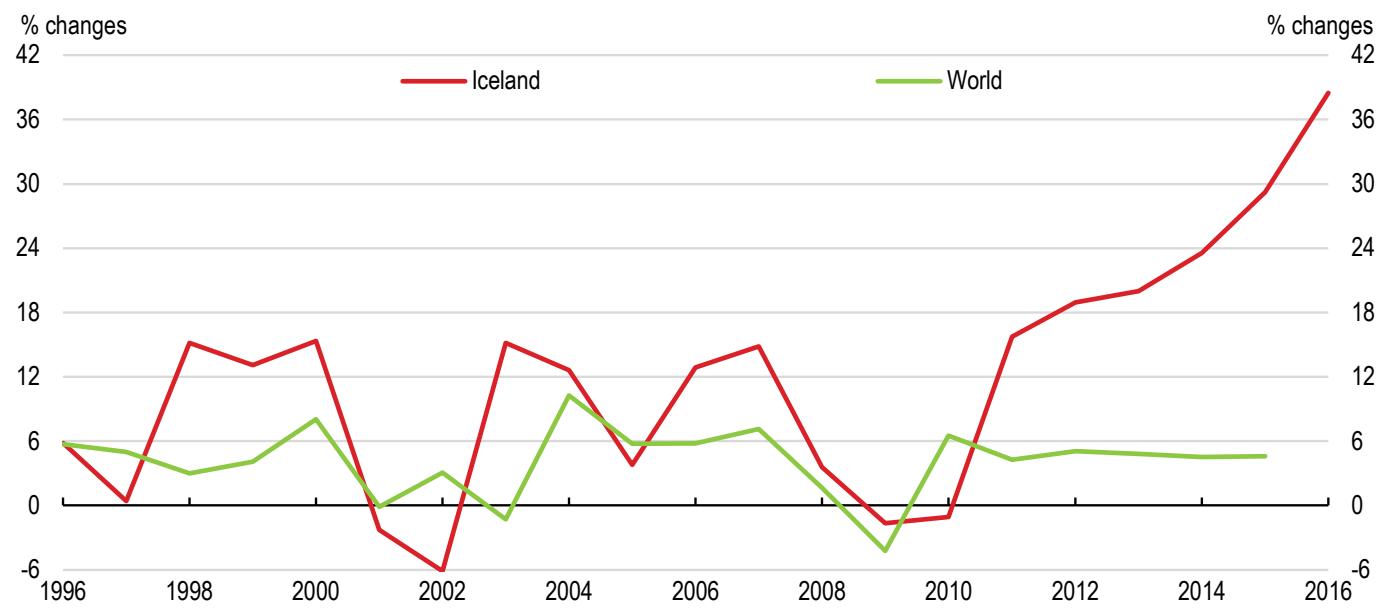

Source: Icelandic Tourism Board; and World Bank WDI database.

\section{Tourist arrivals and demand}

Almost all international travellers arrive by air, with comparatively small numbers arriving by sea (less than 10\%). The overwhelming majority of international visitors (that is those who leave the airport terminal and are not transit passengers as well as passengers on the ferry line) stay overnight (Figure 3). 
Airlines also offer the opportunity for long-haul passengers - transferring flights in Keflavik airport - to visit nearby attractions without staying overnight. The number of daily excursionists has also risen, but not as fast as of all visitors, and now accounts for around $10 \%$ of total arrivals. In the past the majority of tourists came from Nordic countries, which is partly related to proximity and cultural and historical linkages. More recently, North American and the United Kingdom have become important origin markets, while tourism from continental Europe and more recently China has been increasing too.

Figure 3. International visitors are becoming more diversified and mainly stay overnight

A. Total international arrivals

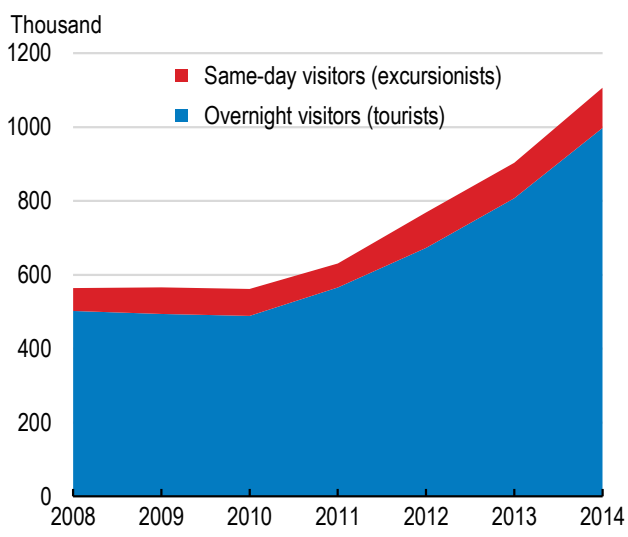

B. Visitors' origin

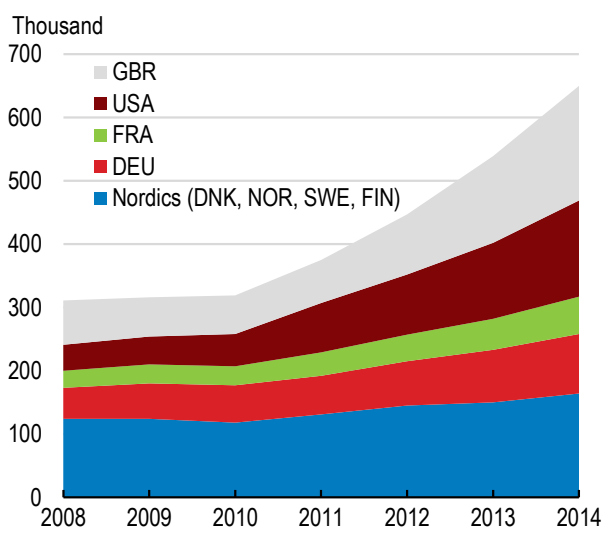

Note: International visitors are only those who leave the airport and excludes purely transit passengers.

Source: OECD Tourism Statistics.

The development of tourism in Iceland builds on past success of offering competitive flights between North America and Europe. During the 1980s and 1990s, flying via Iceland offered a cheap option to cross the Atlantic. Even as deregulation of the transatlantic market began to affect the long-haul airline market, Iceland retained a relatively strong position. In 1998, the national carrier, Icelandair, introduced a hub-andspoke strategy based on Keflavik international airport. Subsequently a number of other airlines have started flying to Iceland, including the low cost companies WOW, EasyJet, Norwegian and Air Berlin, which have contributed to making Iceland a more affordable destination. As a result of this development, Keflavik airport - the main airport close to the capital - dominates international travel (accounting for 95\% of arrivals) with much smaller numbers arriving at the regional airports at Reykjavik, Akureyri and Eglisstadir.

The importance of the Keflavik hub to international travel combined with the large geographical size of Iceland and relative remoteness of many areas determines that most visitors remain in the South West of the country, particularly during the winter when road travel becomes more difficult. Around two thirds of tourists remain in the South or Capital regions, near the location of some major tourist attractions, including the Golden Circle.

Visitor numbers are highly seasonal, with most tourists arriving during the summer months (Figure 4). During the summer the pattern of tourism is somewhat more evenly spread across Iceland. Efforts to lengthen the tourist season have met with some success in recent years, with a rise in the numbers visiting during the winter months outpacing the growth during the summer. Visitors from the United Kingdom, in particular, tend to visit during the winter, whereas a decade before they predominantly came in the summer. According to survey evidence, around two-fifths of respondents during the winter noted that 
cheap airfares were an important attraction, whereas this was noted only by one fifth of respondents during the summer months. This may suggest that the winter segment of the market is more price sensitive.

Figure 4. International travel at Keflavik is highly seasonal

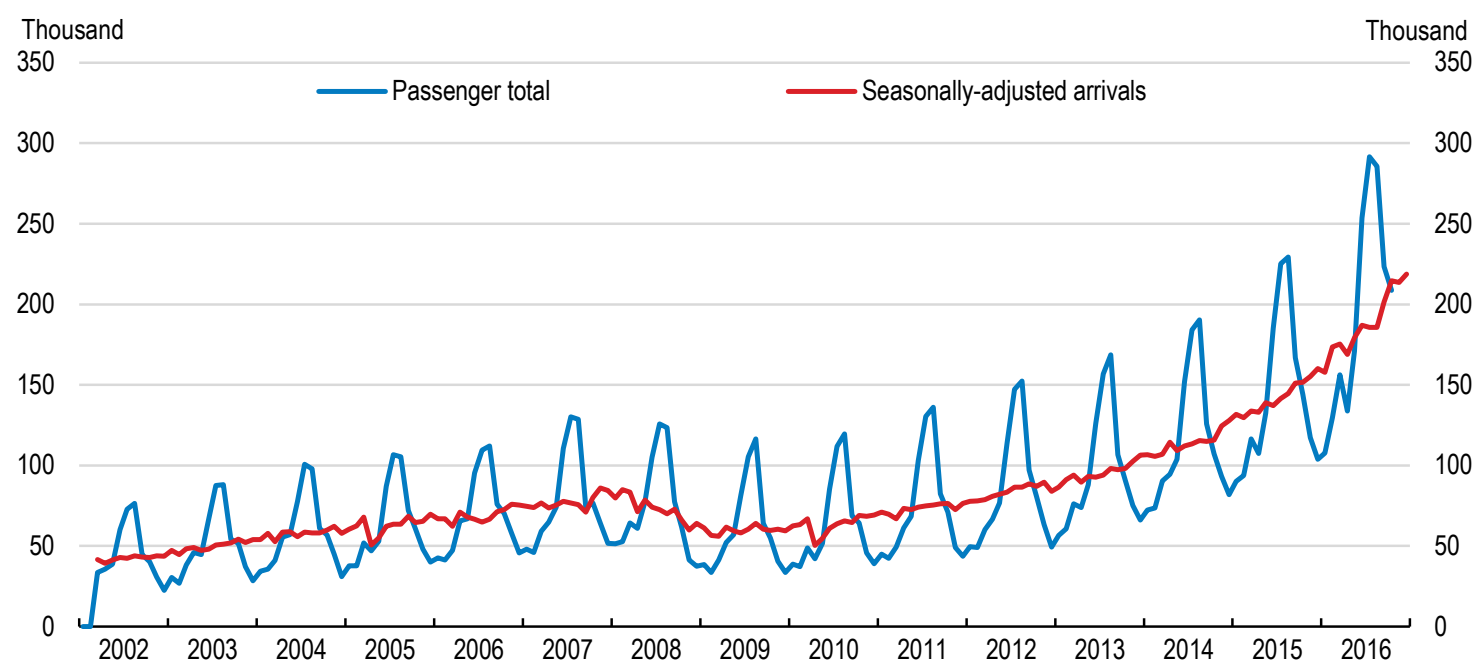

Note: Number of departures from Keflavik airport by month.

Source: Isavia.

\section{Tourism is highly dependent on nature}

Most international visitors come for the purpose of tourism, with travel for meetings and conferences (which are classified as tourism in official statistics) a relatively small share of the market. The pristine state of nature is one of the main attractions (Figure 5). Indeed, around $80 \%$ of international visitors are drawn by natural attractions, such as geyser, or the promise of untouched or unspoilt areas of landscape and wilderness. For example, the area of the Central Highlands is one of the largest wilderness areas in Europe and is visited by around one-third of international tourists during the summer. Other important factors drawing tourists include Icelandic culture and history. Relatively low cost air travel to and from Iceland and the opportunity to take a stopover are also important factors. 
Figure 5. Most visitors come to experience nature

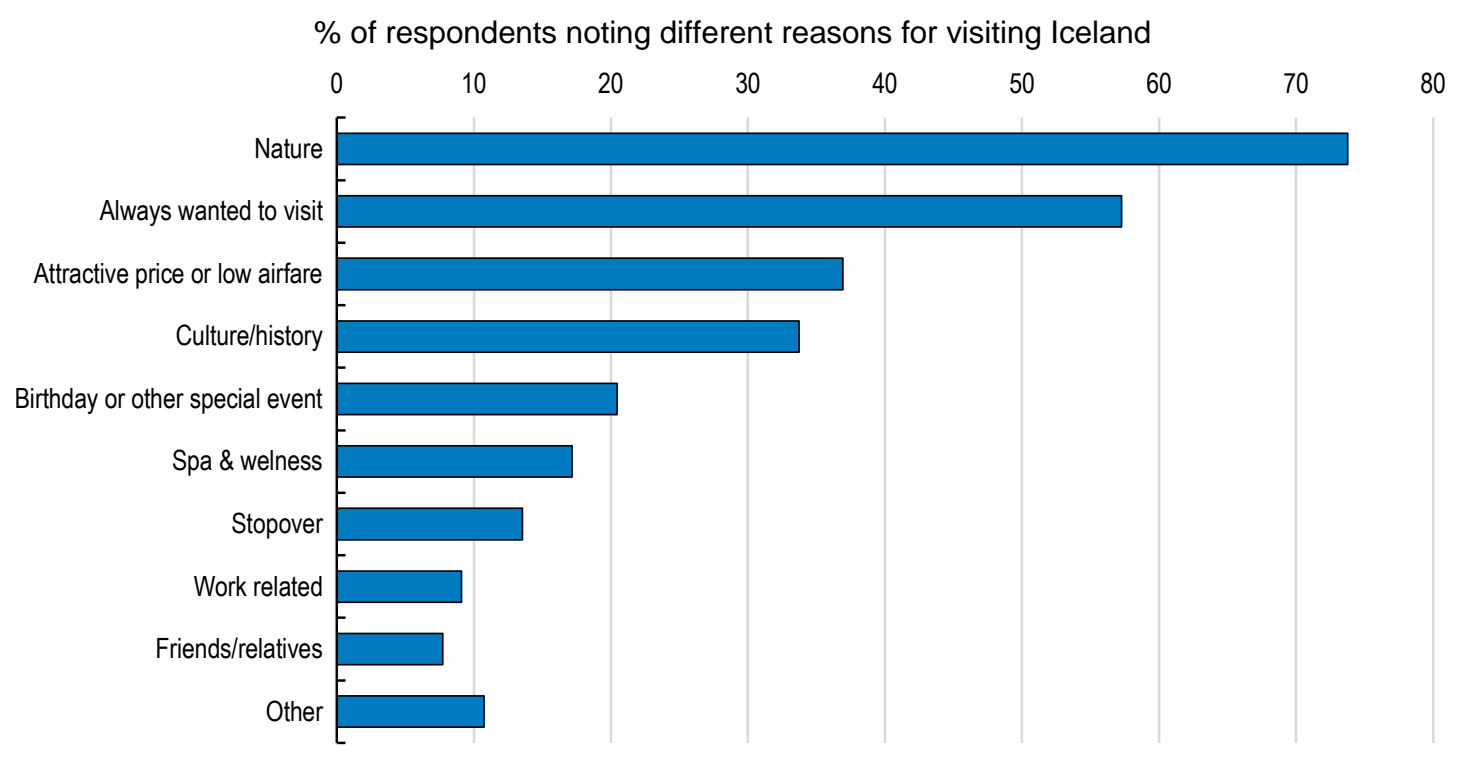

Source: Icelandic Tourist Board Ferdamalastofa (2016a).

The majority of tourists travel independently rather than as part of package tours (which accounts for around one-fifth of visitors). However, over two-fifths of visitors take guided sight-seeing tours once in Iceland. In the summer months, car rentals are an important means for travelling around the country. By contrast, in the winter, when road conditions are more dangerous, buses (mainly private coaches) are relatively more important, although car rentals during the winter months are becoming more common.

In terms of measures of the sustainable development of the tourism sector, Iceland performs well. According to the World Economic Forum's Travel \& Tourism Competitiveness index, in the overall index Iceland ranks 25 out of 141 countries (Figure 6). The relatively good ranking is driven by strong performance along a number of dimensions including human resources and the labour market, international openness, the prioritisation of travel and tourism and to a lesser extent environmental sustainability. A low ranking for ground infrastructure is in some ways misleading as it is distorted by the large land mass and very low population density, while an average ranking for natural and cultural resources reflects the unique biota with a very limited number of known species. The one area where performance is unambiguously weak is price competitiveness, where Iceland ranks in 132h place (World Economic Forum, 2017). 
Figure 6. Iceland is a reasonably competitive tourism destination

Travel and tourism competitiveness index, 2017

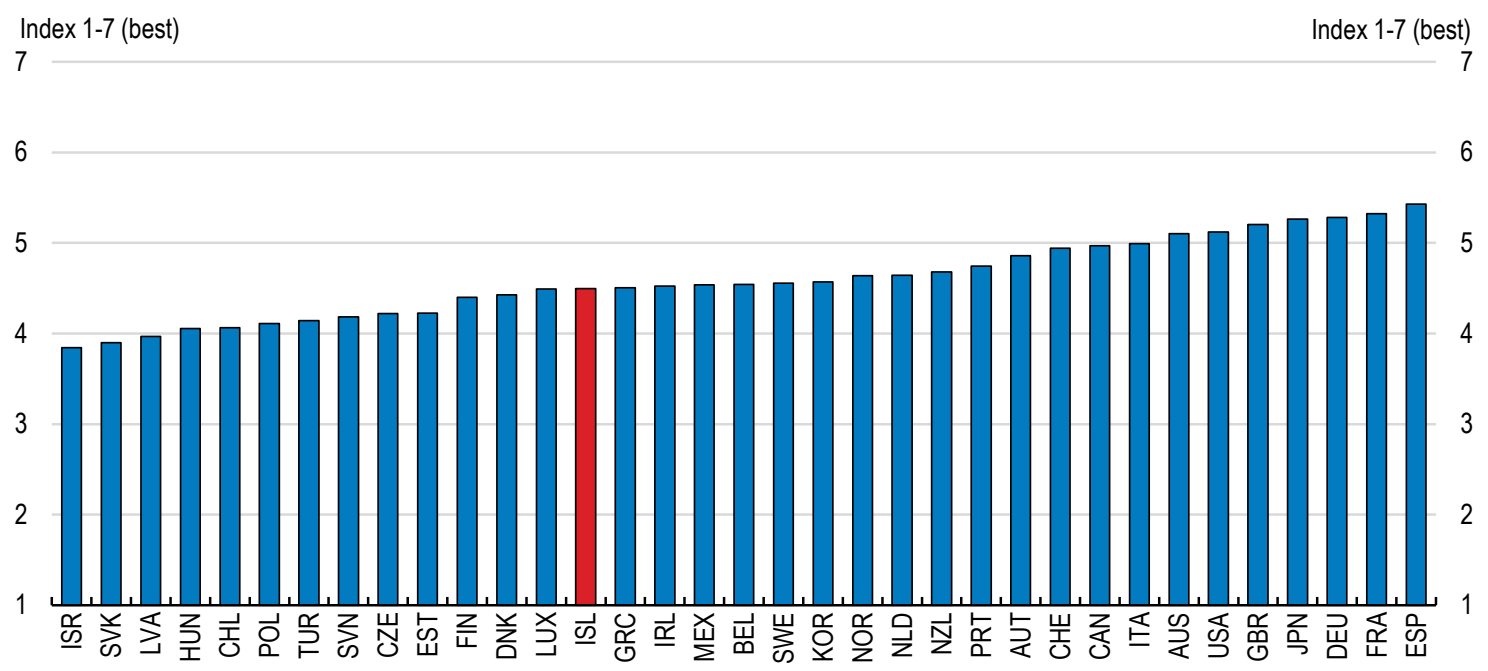

Note: The Travel and Tourism Competitiveness Index measures "the set of factors and policies that enable the sustainable development of the travel and tourism sector, which in turn, contributes to the development and competitiveness of a country". Source: World Economic Forum Report.

Iceland also performs well on another set of rankings that are important for businesses wanting to ensure responsible business conduct in the meetings, incentives, conventions and exhibitions (MICE) market. According to the Global Destination Sustainability Index, Reykjavik ranked second of the 35 cities from 16 countries covered for 2015. This ranking takes into account city-wide environmental and social performance as well as the specific sustainability practices of the Icelandic firms working in the sector. Of the various factors feeding into the index, the sustainability practices of some of the suppliers (hotels and restaurants) are likely to have dragged the overall score down, suggesting some scope to boost attractiveness in this relatively under-developed segment of the tourism market in Iceland by working with suppliers to improve their sustainability performance. Nonetheless, this ranking suggests that Reykjavik has boosted its performance in recent years. Reykjavik's rankings in an earlier Scandinavian Destination Sustainability Index were somewhat weaker.

\section{The impact on the economy}

The growth of tourism has boosted the economy substantially. Tourism has risen from being a small part of economic activity to becoming the major export earner and increasingly important source of employment. The sector's growth has spurred new firm creation. Furthermore, tourism receipts alleviated financing constraints on the balance of payments and boosted government revenues, helping to improve the budgetary position following the crisis.

Export of services has increased significantly with the boom in tourism, rising fourfold between 2010 and 2016. By contrast goods exports increased by just $20 \%$ over the same period. Tourism-related services are now estimated to be the largest Icelandic export category accounting for around two fifths of total exports of goods and services in 2016 (Figure 7). Tourism contributed to the boost in tradables as a share of total output following the crisis and helped maintain the positive trade balance and current account surplus that emerged in 2009. This surplus together with the settlement of the failed banks estates in 2016 has switched Iceland's net international investment position from a large negative after the crisis $(-150 \%$ of 
GDP) to a small positive more recently. On the other hand, higher tourism receipts created pressure for the króna to appreciate. Since the tourism boom began gathering pace in 2010, trade-weighted exchange rate has appreciated by around 40\%, significantly offsetting the large deprecation that accompanied the financial crisis (Figure 8). Overall, with tourism growth expected to continue the Central Bank projects continued króna appreciation by around 2\% in 2017 (Central Bank of Iceland, 2017).

Figure 7. Tourism is now a major export earner

Share of goods and services exports, \%

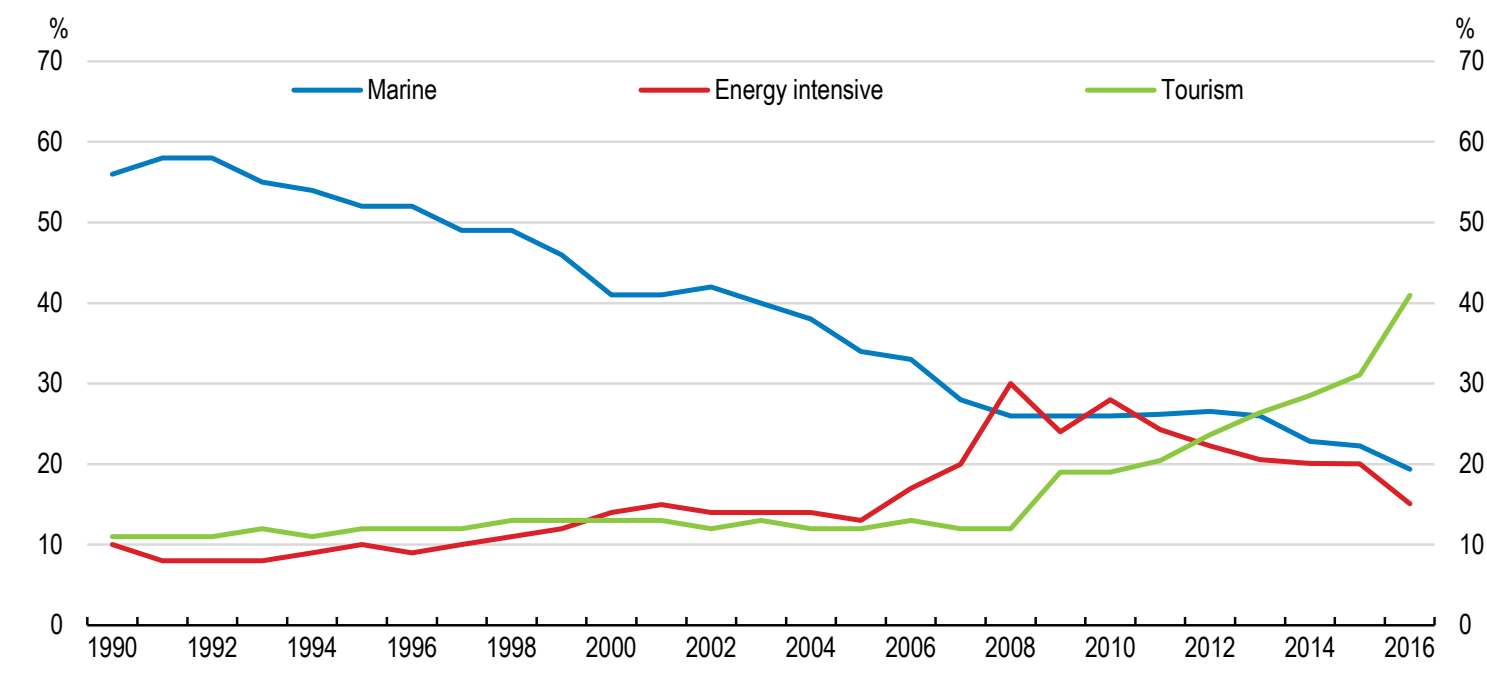

Source: Statistics Iceland.

Figure 8. The króna has appreciated strongly since 2013 Broad trade index

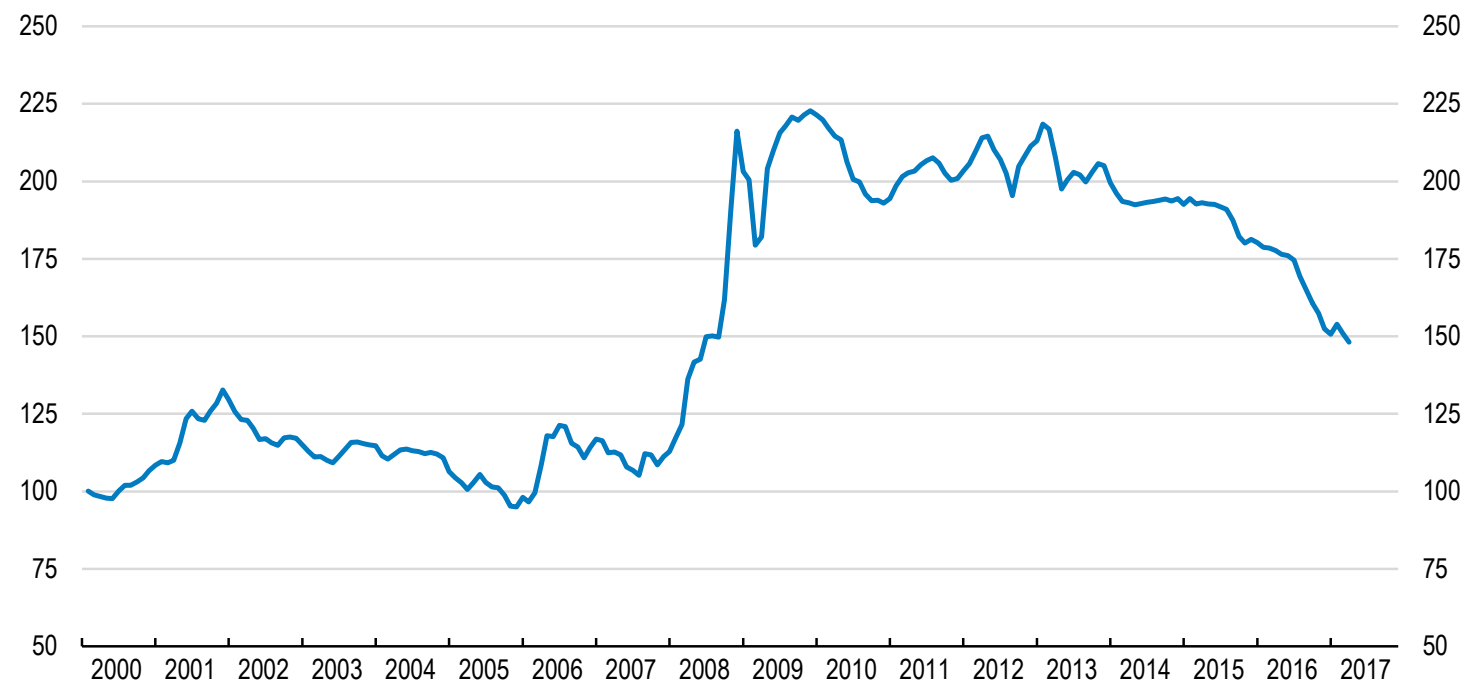

Source: Central Bank of Iceland.

The rapid growth of tourism services (such as travel, accommodation, meals and tour guides) in exports also translates into an increasing share in GDP (measured by the direct impact). The full impact on GDP and employment is difficult to assess as data from tourism satellite accounts is only available with a 
considerable delay. Before the most recent surge in tourist numbers, tourism's share in GDP was below more established tourism destinations, but substantially above other Nordic countries (Figure 9). Estimates of the indirect and induced effects of tourism on the economy suggest that this sector could potentially underpin a much larger share of activity (as much as 30\%), though these estimates are subject to considerable uncertainty (WTTC, 2016).

Figure 9. Tourism represents a sizeable share of GDP and employment

A. Tourism GDP (direct ${ }^{1}$ ) as $\%$ of total GDP

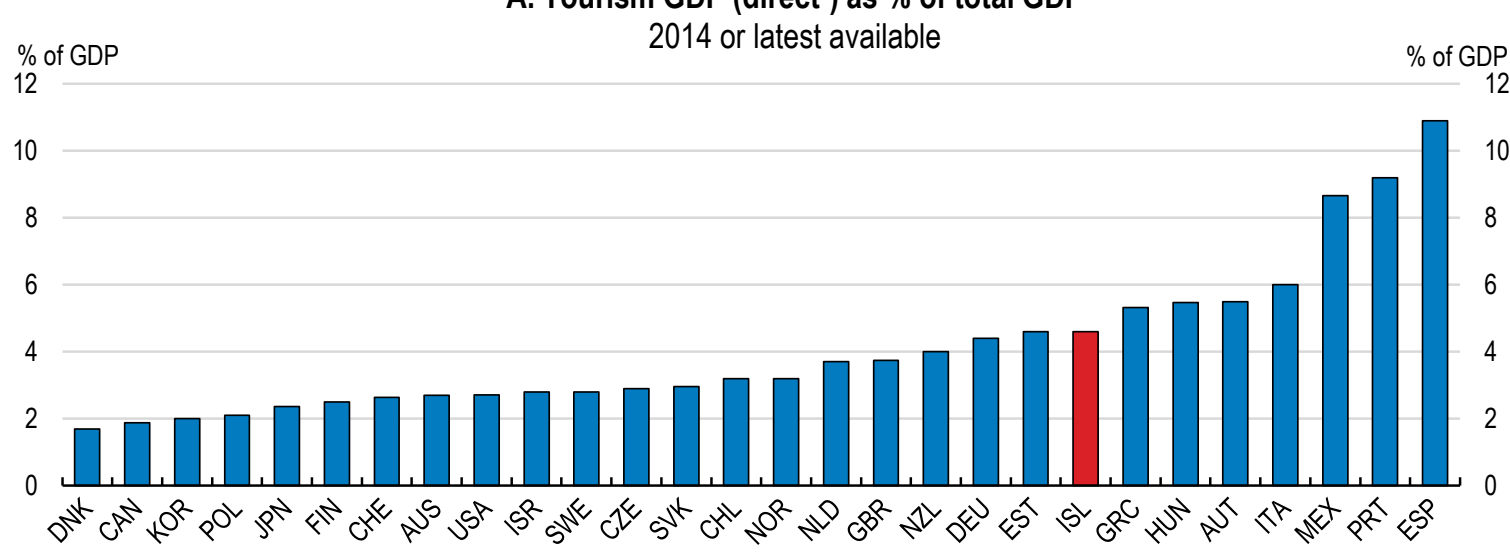

B. Total tourism employment (direct ${ }^{1}$ ) as \% of total employment

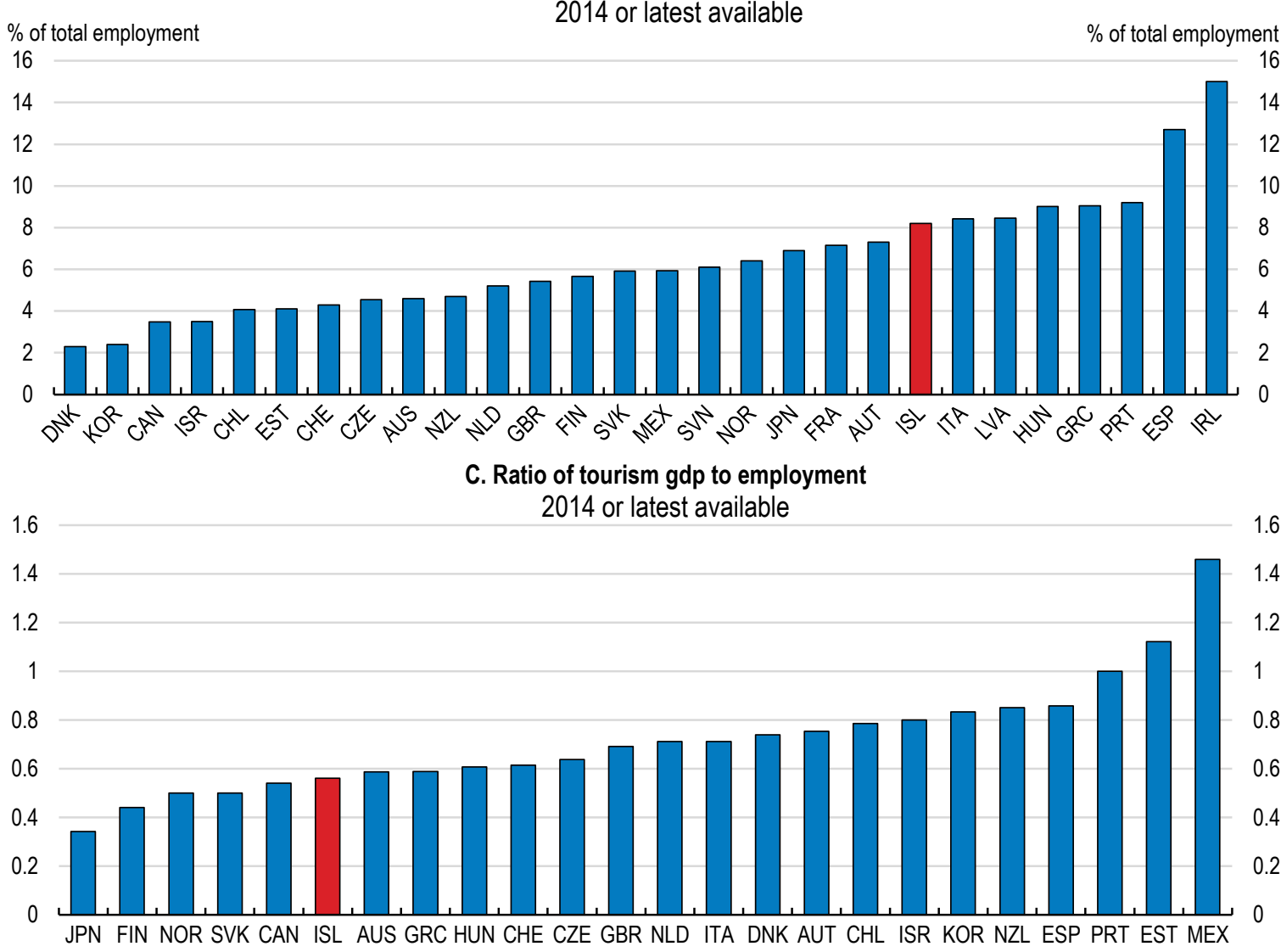

1. Tourism GDP corresponds to the part of GDP generated by all industries in response to internal tourism consumption. Tourism direct GDP is generated by industries directly in contact with visitors, while indirect tourism GDP is generated by industries supplying inputs to industries directly in contact with the visitors.

Source: OECD key tourism indicators database. 


\section{Employment and business sector dynamism}

The rapid pace of tourism development has boosted employment in the tourism sector, with direct employment accounting for just over $8 \%$ in 2014. The larger weight of tourism in employment than in value added suggests that labour productivity remains low relative to the economy-wide average (Figure 9). Measuring productivity in the tourism sector is difficult, partly because tourism cuts across so many different parts of the economy. While some estimates of labour productivity suggest that productivity is weaker than in fishing and metallurgy, the evidence does not suggest it is significantly out of line with tourism sectors in the Nordic economies (McKinsey, 2012). Nonetheless, tourism has become an important pillar of the economy and generates a substantial resource rent that benefits the economy.

A second characteristic of employment growth is the rising share of migrant workers in the labour force, partly reflecting the labour intensive nature of tourism services as well as construction. Immigration is nothing new for Iceland, particularly when the economy is booming (Figure 10). Strong inflows and then outflows were observed around the financial boom and immigration is again rising strongly. The new wave of immigration has raised the share of foreign citizens to $8 \%$ of the population in 2016, which now surpasses the previous peak reached in 2009. Despite past experience with strong migration flows, the new inflow is raising concerns about the number of foreign workers the country can absorb, the impact on housing and provision of other services, and their lack of local knowledge. In some cases, such fears likely represent growing pains while migrant workers become better integrated. Temporary workers in other major tourist destinations are often more likely to suffer from job insecurity and poorer or irregular working conditions. In Iceland's context, the collective bargaining agreements ensure that the same negotiated wages and conditions are enjoyed by all workers and as the tourism season lengthens employers have stronger incentives to offer attractive conditions to retain potentially foot-loose workers. However, for more task-based activities (such as on construction sites and some services such as minibus rentals) there are rising concerns that the number of unregistered workers is growing.

Figure 10. Immigration is rising strongly, though many continue to leave

\section{A. Foreign nationals}

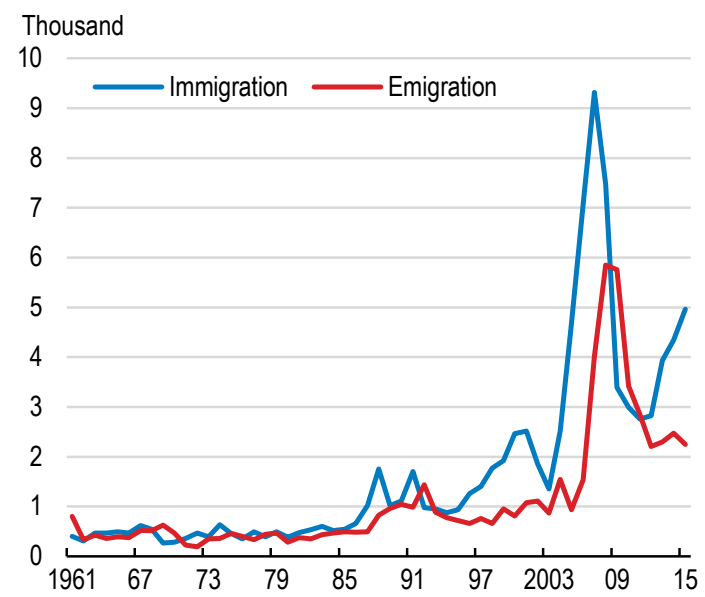

\section{B. Icelandic nationals}

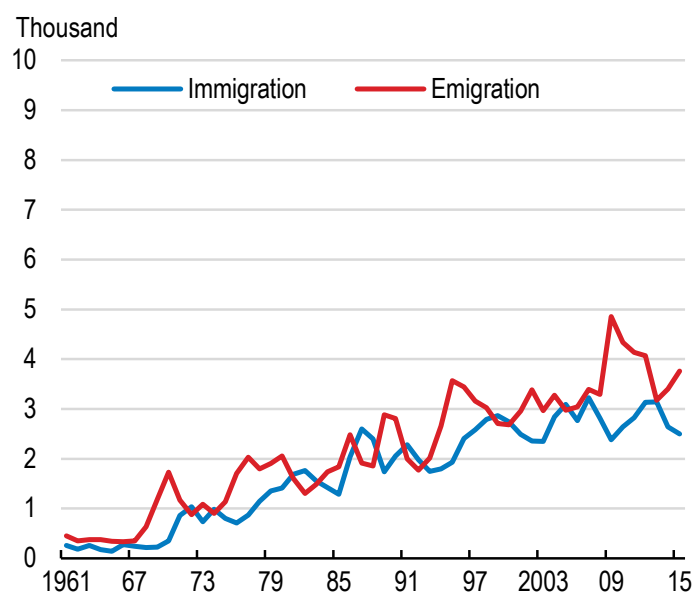

Source: Statistics Iceland.

\section{New business creation}

The growth of the tourism sector is providing a spur to business formation. The number of registered enterprises and organisations has grown by almost one quarter since the crisis (Figure 11). The growth 
includes an additional 300 hotels, and over 1000 new enterprises in the real estate and rental market. In addition, over 800 enterprises have entered the travel agency and tour operator sector. One of the current strengths is the large number of small businesses offering a very wide range of activities. Furthermore, the expansion of the sector has had indirect effects on other sectors and through this channel has supported construction activity with the building of new hotels and other tourist related infrastructure, although with some lag. Employment in the construction sector was severely ravaged by the crisis, but has picked up as construction activity has rebounded. A further knock-on effect of the growth in tourism has been the opportunity to make use of airline cargo capacity to export goods, notably fresh fish, to new markets. For example, according to US Department of Transportation statistics, freight carried by airlines from Iceland to the United States almost doubled in weight between 2009 and 2015 with Icelandair accounting for the overwhelming majority of this freight $(90 \%)$ and specialised cargo companies largely accounting for the rest.

\section{Figure 11. Employment and firm creation in tourism services is growing robustly}

\section{A. Enterprise numbers}

B. Tourism employment
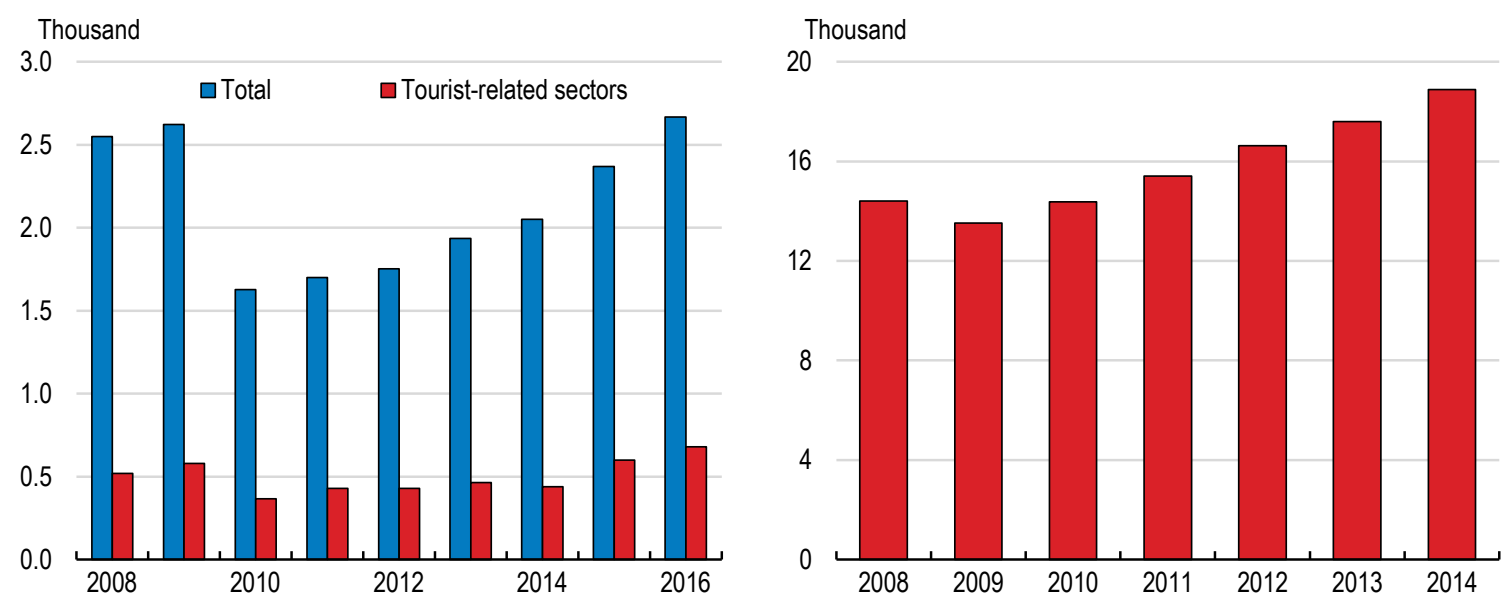

Source: OECD key tourism indicators database, Statistics Iceland.

Since the boom of tourism started, the number of nights spent in hotels has more than doubled. While the total number of overnight stays has increased, the average length of stay has not increased much and remains around 7 nights (in 2016). Due to the highly seasonal pattern of visits, average occupancy rates in 2015 were around $65 \%$, but in the summer months they rise to around $90 \%$. In the capital region and a somewhat lesser extent in the South - where most hotels are located - occupancy rates remains elevated throughout the year. Since 2010, over 9,000 rooms have been added and the number of hotels and guesthouses have risen by around two-thirds (Ferdamalastofa, 2016a). Ongoing hotel construction is adding more capacity, but not enough to counter the ongoing rise in room occupancy rates (Figure 12). By the end of 2015 there were almost 400 hotels and guesthouses with over 13,000 rooms. Even though capacity has been added, demand for accommodation has been rising very strongly and private rentals such as Airbnb - have been meeting a growing share of the demand. As such, while the total number of nights more than doubled between 2008 and 2014, private rentals grew tenfold and now account for over $10 \%$ of total overnight stays. 
Figure 12. New accommodation is being added, but occupancy rates keep rising

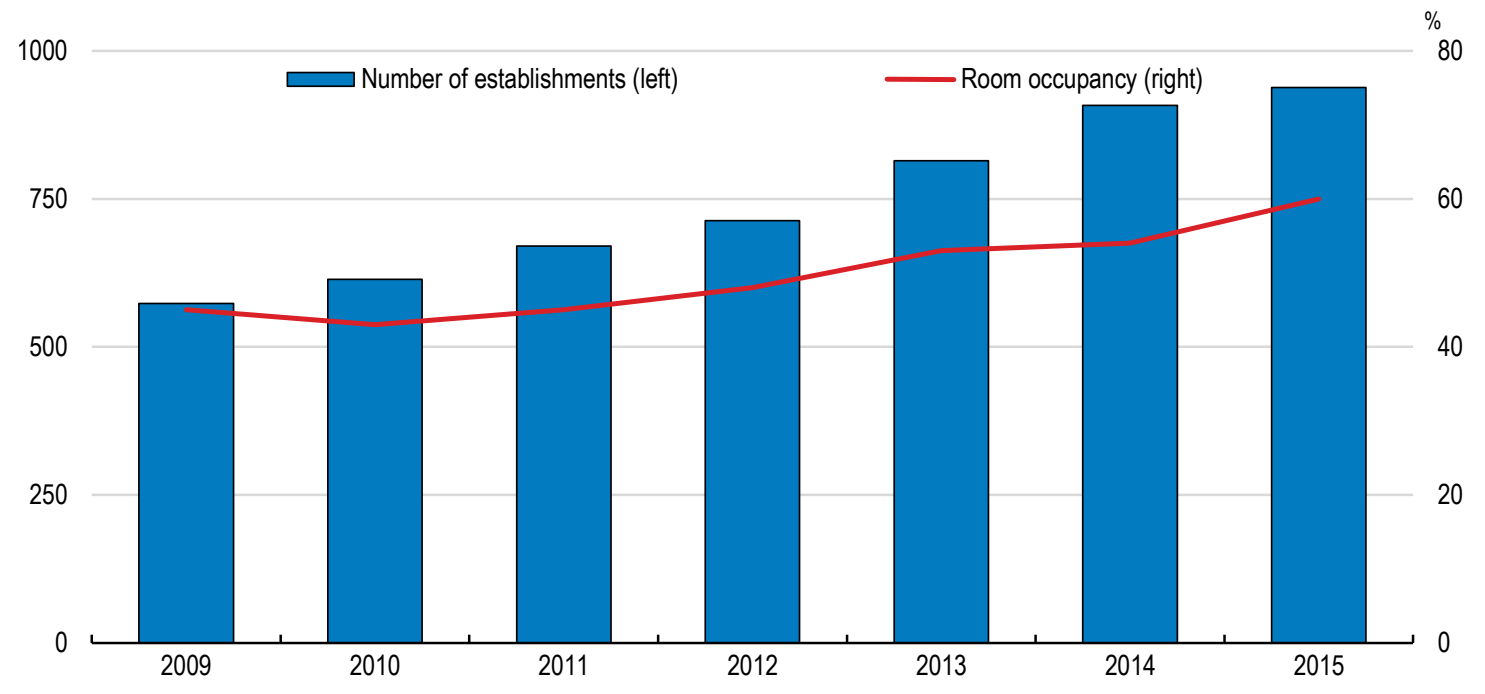

Source: Statistics Iceland.

\section{Iceland is becoming a more expensive destination}

In the aftermath of the financial crisis and large króna depreciation, the cost of visiting Iceland became cheap in comparison with competing destinations, such as other Nordic countries and areas basing their appeal on nature, such as Alaska, Canada and New Zealand. However, more recently the strong inflows of foreign currency have put upward pressure on the exchange rate. Indeed, since the start of the tourist boom in 2010 the effective exchange rate has appreciated by $40 \%$. Bilateral exchange rate movements have made Iceland a much more expensive destination for some markets, notably Norway and the United Kingdom (Figure 13). In the short-term the exchange rate appreciation will have a limited effect on some tourism prices due to multi-year pricing agreements with tourist agencies and tour operators. For more exposed businesses, however, an inability to adjust prices due to long-term agreements denominated in foreign currencies will eat into profits. Over time prices will adjust, particularly if the sector begins to price in króna rather than foreign currency, making Iceland less competitive with other destinations. Prices for some tourism services are already rising at breakneck speed. For example, the price index for hotel accommodation was rising by an annual rate of $20 \%$ in early 2017 . While Iceland is a very attractive tourist destination, it is expensive and the appreciation and rising prices will impact tourist spending and numbers (Box 1).

Rising costs and exchange rate appreciation are also giving rise to fears of Dutch disease, which for the tourism sector is sometimes dubbed "beach disease" (Holzner, 2011). As the tourism sector booms and draws in more resources this demand puts upward pressure on domestic wages and prices. However, the internationally-exposed sectors (In Iceland, fisheries, metallurgy and some technology firms) face prices set on international markets. These sectors have been affected by the effects of króna appreciation and strong wage increases as a result of the wage bargaining rounds. 
Figure 13. The exchange rate has begun to appreciate, unwinding some of the depreciation after the crisis

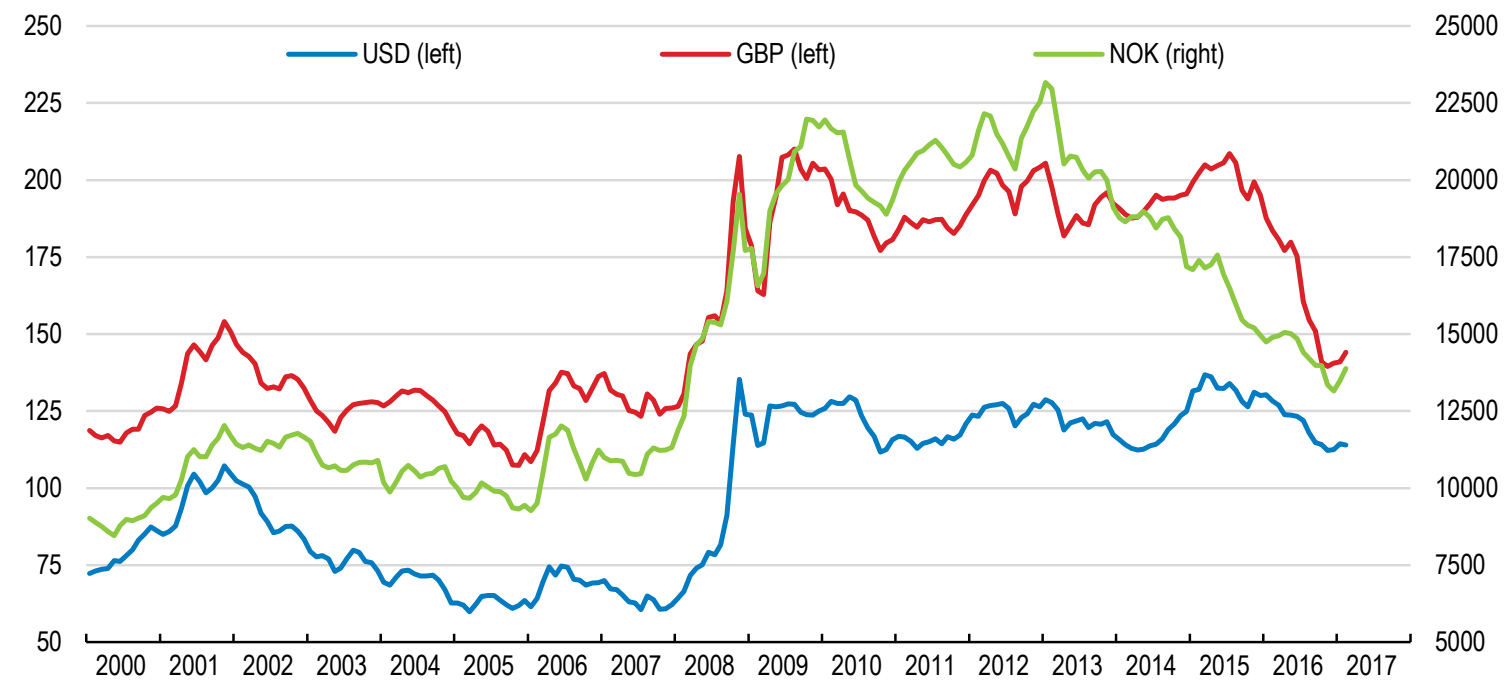

Source: Central Bank of Iceland.

\section{Box 1. Tourism booms, slowdowns and risks of reversal}

The growth of international visitors to Iceland is unlikely to be sustained at recent rates. While a slowing is to be expected, Iceland's tourism boom is arguably reasonably balanced and less susceptible to idiosyncratic shocks in the origin countries of tourists. Iceland benefits from being an important destination for both short and long-haul travel. In addition, visitors are drawn from a relatively well diversified range of countries, making tourist flows less sensitive to developments in individual markets. For example, while tourists from the Nordic countries accounted for $22 \%$ of all tourists in 2008, the share dropped to $15 \%$ in 2014 despite the numbers not declining, principally due to greater numbers of tourists arriving from North America and the United Kingdom. Furthermore, the recent growth in tourist numbers reflects growing interest in wilderness environments, which has also boosted tourism in similar markets (such as New Zealand and wilderness areas in other countries near the Arctic Circle). Thus, Iceland's tourist are a mix of travellers taking the opportunity of taking a layover and those more interested in visiting wilderness areas and participating in nature-based activities, such as whale-watching.

There have been a few episodes of past run ups in international tourist numbers in other OECD countries. Tourist numbers have been growing on average globally for a number of years, but countries have experienced quite different dynamics. Some destinations where tourism has been a relatively small sector of the economy have also enjoyed spectacular growth, such as Japan. Strong growth has also been seen in Portugal, the Slovak Republic and Spain, where some of the tourism flows appear to have been diverted from other destinations. Many traditional tourist destinations have witnessed little growth in numbers and some suffered in the wake of the global financial crisis. In extreme cases, tourism has slumped, such as in Turkey in the wake of terrorist attacks and heightened geopolitical tensions, while Finland initially suffered due to the economic slump in Russia affecting its principle origin market. Thus, while projections for global tourism see continued steady growth in tourist numbers of between 2.5 to $4 \%$ annually to 2030 (WTO, 2011), country specific factors can be capricious.

\section{The impact on public finances}

The growth of tourist numbers has provided a boost to fiscal revenues, although the exact extent of the contribution is difficult to gauge (related to the difficulties in splitting out tourism from non-tourism activity). Nonetheless, turnover showing up in VAT receipts in tourist-related sectors has been rising strongly (Figure 14, panel A). Furthermore, estimates of net receipts have moved into surplus in recent years (in 2016, net VAT receipts were estimated to be 2.7 billion króna). Revenues from tourism have been boosted by reforms introduced since 2015 , which broadened the tax base by removing exemptions and raised the reduced rate from $7 \%$ to $11 \%$, while lowering the standard rate for VAT from $25.5 \%$ to $24 \%$. 
The reduced rate applies for most tourism related goods and services. The base broadening had an immediate effect in 2016, with the share of turnover from travel agencies and tour operators jumping from almost nothing beforehand to account for one-quarter of total taxable turnover (Figure 14, panel B). Passenger land transport, mainly private coaches, also increased and now accounts for around about $6 \%$ of turnover. Due to the increase in the reduced rate, revenue from hotel and other accommodation rose in 2015 relative to 2014 without any discernible impact on tourist numbers.

Figure 14. VAT base broadening has had visible impacts

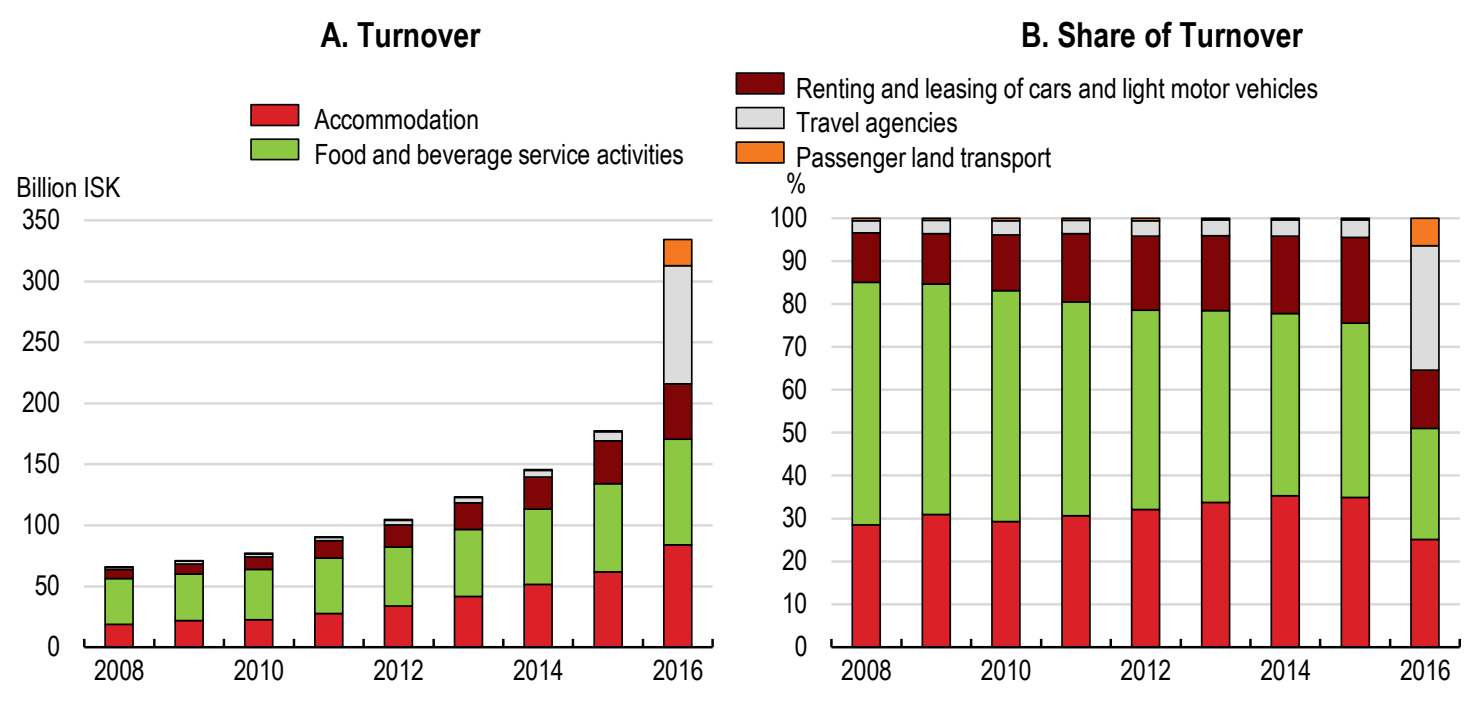

Source: Ministry of Finance.

The government has made a proposal to go further in reducing remaining advantages enjoyed by the tourism sector. With the exception of restaurants, the VAT rate applied to most tourism services will be changed to the standard rate. As part of the proposed reforms, the standard rate will then be reduced further from $24 \%$ to $22.5 \%$. There are a small number of tourism-related services that continue to lie outside the VAT base (including salmon fishing and taxis) and which the authorities should bring into line with other tourism-related services.

Another tourist-related revenue source is the occupancy tax, which was introduced in 2012. The rate has been only 100 króna per unit per night (where the unit refers to the transaction and can cover a single room or a house, rather than per person, which is the usual tax base in many cities). Accommodation taxes levied in other European countries (often at the city level) are often around $€ 2$ per person per night (226 króna) and in some cities can rise much higher, such as Rome where the hotel tax can reach $€ 7$ per person per night (or around 800 króna). In this context, the authorities should go ahead with their intended raising of the occupancy tax to 300 króna and consider changing the basis from per unit to per person. Other revenue sources from tourism are relatively small. Few user fees are applied with port fees for cruise liners being an important exception for some municipalities.

On the spending side, direct budgetary outlays have been relatively modest. In 2015, spending supported the Icelandic Tourist Board (357 million króna), promotion and marketing activities (452 million króna) and other services (243 million króna). Other spending included the Tourist Site Protection Fund (177 million króna), which is partially funded from the tax on overnight stays (158 million króna). Maintenance and investment in infrastructure at tourist destination accounted for an additional 848 million króna. In total these sums accounted for a small share of government spending. However, indirect spending has been mounting with increasing tourist numbers. For example, the health sector has witnessed strong 
increases in tourism-related service use. Similarly, the police and rescue services have had to respond to ensure the safety of tourists in an often hostile natural environment.

Tourism-related spending can create particular difficulties for the municipal governments as local revenue sources are not sufficient to meet rising spending pressures. Local governments are responsible for local infrastructure, planning and environment. At present, the mismatch between revenue and spending pressures can be substantial in some of the most heavily visited areas. But pressure on local public finances can also emerge in less visited areas where infrastructure upgrades are most pressing. Municipalities can be very small and rely largely on income taxes, which limits how much revenue is available, which is particularly a potential problem when the municipality contains a major tourist attraction.

At present, the municipal governments raise relatively little revenue directly from tourism activities. The occupancy tax (while expanding the base to a per capita basis) would provide one revenue source that could be shared with the municipalities. Moreover, this source of revenue for the municipality would provide some incentive to develop tourist destinations around Iceland. However, support from the central budget is likely needed in the day-trip destinations where public services are demanded but few tourists stay overnight. Introducing user fees, particularly where congestion and environmental damage are problems would provide another revenue source. Recent changes to the law to allow parking fees to be levied outside urban areas would provides additional revenues to match increased municipal expenditures.

Fiscal rules introduced in 2011 introduced caps on municipalities' debt levels (up to $150 \%$ of regular income). This has contributed to some spending restraint on needed investments as the municipalities have been reducing debt levels to ensure compliance with the new rules. As progress has been made in reducing debt loads, some of the backlog is beginning to be addressed, although this may come at an inappropriate point in the economic cycle. The central government and the municipalities need to co-ordinate investment plans to make sure that they are not destabilising to the economy.

\section{Ensuring tourism is sustainable and inclusive}

Tourism interacts with a number of other policy objectives. Most notably, tourism affects the very environment most tourists come to experience. The impact of tourism is also felt through aspects of the economic development it encourages, requiring specific skills and infrastructure, putting pressure on access of housing and affecting productivity. In some cases, these impacts are likely to be temporary arising from the growing pains of a rapidly developing sector. In many ways, developing the appropriate policy framework will benefit both the tourism sector and allow Iceland to maximise the gains for the population while protecting the assets upon which tourism is built.

\section{Developing nature-based tourism while managing the effects on the environment}

The surge in tourism has put the environment under renewed pressure. Soil in Iceland is largely volcanic and particularly susceptible to erosion while vegetation is also vulnerable. As tourism has surged more recently some popular sites have suffered environmental degradation. At present, these concerns largely relate to tourist flows at a number of popular sites in the south and southwest of the country, notably along the Golden Circle route. A second factor affecting the landscape is that the lack of tree cover makes manmade structures hard to conceal. Estimates of the surface area of pristine nature without proximity of manmade structures are around one-third of Iceland, mainly around the ice floes (Olafsdottir and Runnstrom, 2011). Preserving the attraction of nature, while maximising the benefit for Iceland and experience for tourists, requires policy to avoid significant loss of wilderness, including by controlling tourist numbers (Box 2). Environmental damage in some spots will likely be irreversible, particularly in areas where anthropogenic impacts can persist for hundreds of years (a factor behind a ban introduced on off-road driving throughout Iceland). 


\section{Box 2. Tourist numbers and the environment}

Maximising the benefits from tourism needs to consider the impact of tourists on the environment and the capacity of the environment to regenerate on the one hand and the willingness to pay of the tourist, on the other, which is dependent on the state of the environment and the number of other tourists.

New work exploring this issue is presented in Daubanes et al. (2017). This work shows that the relationship between tourist numbers and how quickly the environment can recover can be described by the blue line in Figure 15 . The impact of visitors on the environment is stable along the blue curve (more visitors would lead to the environment being damaged by more than it can recover). If the environment is already badly damaged it can only regenerate slowly and thus only a few visitors are possible. The rate at which nature can regenerate rises as the damage becomes smaller and slows again when the quality of the environment is very high (e.g. the marginal areas are those where conditions are harsher and more susceptible to damage so to maintain that quality only a small number of tourists is permissible). If left untouched, environmental quality would end up at the point of maximum environmental quality.

\section{Figure 15. Maximising the number of tourists is not the best strategy}

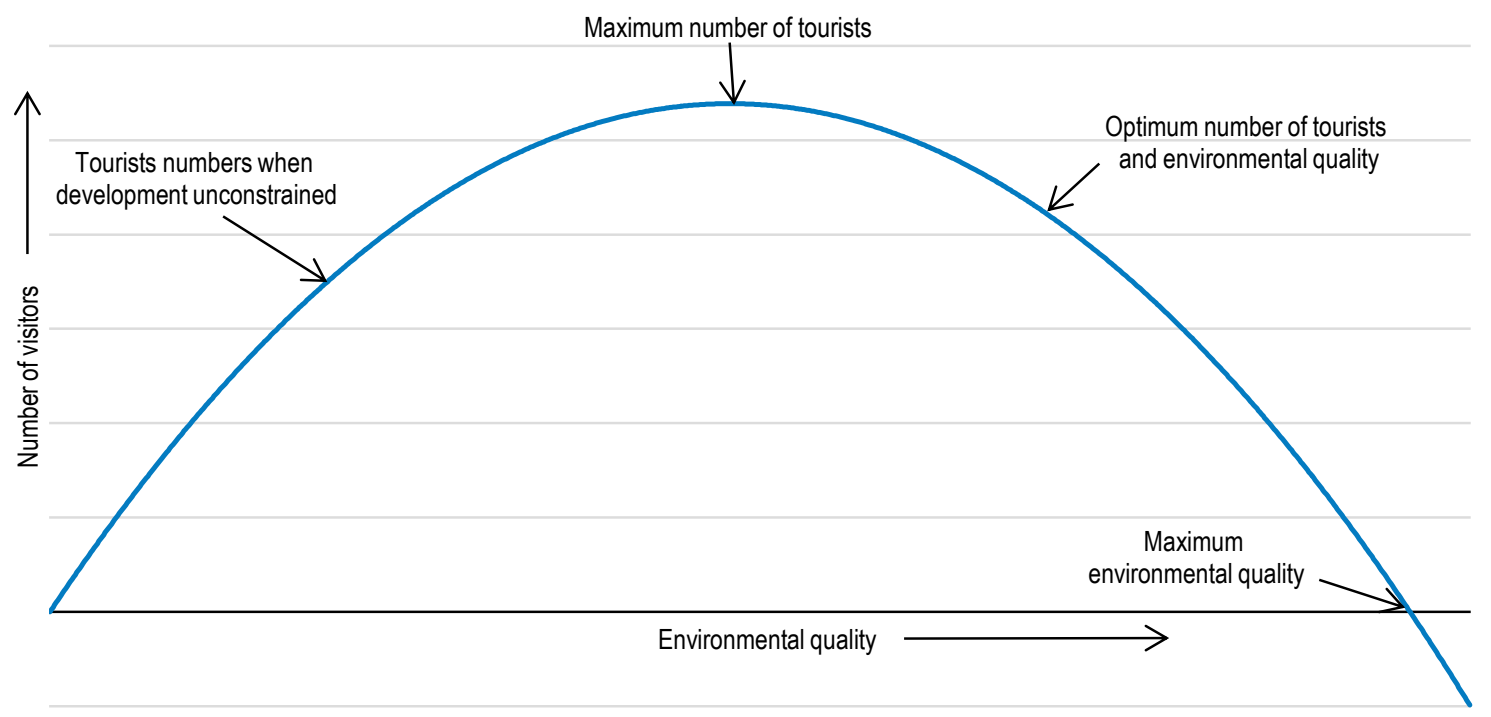

Source: Daubanes et al. 2017 (forthcoming).

As the number of tourists increases their willingness to pay falls and the cost of accommodating the tourists (e.g. providing infrastructure) rises. In this case, when maximising the benefits net of the costs, environmental quality (optimum in figure 15) will be greater than the case of the maximum sustainable number of tourists (at the peak of the blue curve) and below max. The maximum economic benefit is experienced when tourist numbers are below the maximum number of tourists that could be sustainably accommodated. This will also lead to a state with a higher environmental quality.

When the development of tourism is unconstrained, the sustainability of tourism and environmental quality are not taken into consideration. This leads to lower environmental quality, which will ultimately reduce the number of tourists that can be sustainable and lower willingness to pay, which reduces the economic benefits of tourism. Unconstrained development could ultimately result in a depleted environment that is no longer capable of sustaining large numbers of tourists. The research shows that market instruments can correct this outcome and in some other cases limiting the numbers of tourists may be beneficial. 
A number of existing policies serve to mitigate pressure on the environment. During the 1990s, the value of preserving unspoilt natural areas gained traction leading to the Nature Conservation Act of 1999, which established 31 protected areas, including national parks and nature reserves. These protected areas account for around 20\% of the total land. Also in 1999, the Ministry of the Environment and the Planning Agency established a Regional Plan for the Central Highlands - one of the main attractions for naturebased tourism. The plan aimed to ensure the use of natural resources in a sustainable manner, restricting building to the periphery as much as possible and mapping and protecting the areas with the greatest interest for conservation (Gunnarsson and Gunnarsson, 2002). Policy at this time also introduced the need for planning and licensing for all buildings (Saethorsdottir and Saarinen, 2016).

In some wilderness areas, tourists appreciate the low number of other tourists. As tourism continue to grow and larger numbers explore outside the capital region, the relative attraction of the wilderness can begin to diminish. Survey evidence already suggests that tourist numbers in some areas of the Central Highlands exceed desired levels and around 30\% of visitors would advise other travellers to avoid these areas (Saethorsdottir and Saarinen, 2016). Visitor satisfaction surveys also indicate that the density of tourists at popular sites is starting to have a negative impact on the visitor experience, with over $50 \%$ of respondents in some cases saying there were too many other visitors (Ferdamalastofa, 2016b). However, Iceland is a large island with very low population density outside the capital region and with abundant natural attractions, which suggests that better management of tourism flows would allow the country to host many more tourists without bumping into real constraints. In this context, the challenge in maximising the benefits from tourism is to provide the necessary infrastructure to enable tourism while protecting nature, preserving wilderness and providing relative solitude.

Providing information to tourists on expected numbers in different locations may help to disperse tourists across wilderness areas, allowing those that prefer relative isolation to find suitable locations. Such an approach requires efforts to identify which locations hold the greatest appeal to different target groups and developing them (or not) accordingly (Saethorsdottir, 2010). Armed with this information the tourism authorities and industry can develop "touring routes" to spread visitors more widely. In a number of other countries, these routes are based on geographically dispersed concept of 'destination', often structured around a story. For example, Norway's National Tourist Routes and Ireland's Wild Atlantic Way are based on this approach while also seeking to make better use of existing infrastructure. In the case of New Zealand, developing cycling routes to support new touring routes promotes sustainable transport.

Initial efforts to protect the environment and manage congestion have encountered some difficulties. Attempts to introduce pricing at one popular site failed to gain traction. In part this was due to the fee appearing excessive. In addition, restricting access is controversial in Iceland due to the tradition of "right to roam". Nevertheless, protecting the environment in the areas under greatest pressure and preserving the attraction of the most popular sites remains a concern. Norway where a similar "right to roam" tradition exists is also grappling with how best to protect the environment and is contemplating where limits on the right to roam may be required. Against this background, stresses on the environment need to be monitored and policy adapted to preserve areas of wilderness and meet tourist expectations, or risk losing Iceland's unique attractiveness.

Other countries have attempted to limit the human footprint through a number of schemes. In some cases, numbers can be managed by setting quotas and pricing access to enter particular areas. For example, the Great Barrier Reef Marine Park in Australia adopted an integrated zone management approach, taking into account a range of activities including tourism. Tour operators require permits and granting longer permits to accredited tour operators can better ensure the quality of the visitor's experience. One focus of the Australian approach was to improve sustainability through better governance and spatial planning (OECD, 2014). The charge on visitors varies according to the type of tourism and is collected by the tour company organising the visit. The park authorities use this information to monitor usage and this helps the 


\section{ECO/WKP(2017)54}

authorities better manage sustainability and provide for tourist preferences. In the United States, the national parks may charge entry fees and in some cases set limits on the numbers staying overnight. Tourism at the Grand Canyon in the United States relies on a number of approaches covering commercial and non-commercial tourism. The intention is to maximise the visitor experience, which requires imposing quotas in some areas. For example, access to the river itself for non-commercial users is based on a lottery (which replaced a 20 year long waiting list). When plants are at their most fragile, visitors are not allowed in certain areas (IUCN, 2014).

Concessions for commercial operators could serve as a viable alternative to entrance or user fees at some sites. A licensed-based approach for concessions could incorporate criteria prioritising operators with sustainable business practices and be linked to the domestic VAKINN Quality and Environmental certification scheme (Box 3). A further advantage of a concession scheme would be the ability to incorporate dynamic pricing and time or parking slot management to maximise benefits, building on the model successfully introduced by the popular Blue Lagoon site. Concession schemes have been used with some success elsewhere, such as the United States National Park Service. A downside of concession approach is that independent visitors would fall outside this system. Indirect approaches including parking fees, which are already in place at some sites, would ensure these visitors fall into a complementary scheme.

\section{Box 3. Environmental certification}

As the tourism sector has developed and new firms have entered the market, government policy has shifted to address tourist safety and professional standards by firms in the sector. As part of this approach, the VAKINN scheme launched in 2011, represents the official quality and environmental system. Participation in the VAKINN scheme is voluntary and industry participation has grown over time. One aspect of eco-certification is the presence of several international schemes which may have relatively little effect on tourist choices (Karlsson and Dolnicar, 2016). With the introduction of a new scheme, efforts are needed to communicate effectively and encourage wider dissemination of good practice in the tourist sector. This can have an important advantage to the business market as ensuring sustainability is potentially important in attracting companies that need to comply with corporate social responsibilities and require supply-chain sustainability. Linking concession terms to certification is one means to encourage greater participation and improve quality standards in the industry.

However, these user management and concession schemes can be costly to administer and enforce. The current approaches adopted in Iceland such as relying on parking charges may be a suitable approach in some sites. Lifting the restrictions on parking charges outside urban areas would help spread its applicability. In other countries, such as Norway, making use of service fees at popular destinations could also be used in parallel while still respecting the 'right to roam' principle by not imposing access fees.

A particularly acute form of congestion can arise with cruise ships. Arrivals of international cruise ship passengers can create congestion as well as other negative externalities. Due to the large size of modern cruise ships, overcrowding can develop at certain landing spots, especially in small Icelandic fishing towns. This can occur both at dockside when berths are unavailable as well as at landside when cruise tourists visit local attractions en masse and put pressure on publically-provided services. This is becoming a mounting issue in Iceland with strongly rising number of cruise line passengers (Figure 16). Options to address this include administratively staggering the landing times for cruise ships, investing in infrastructure to relieve the chokepoints and introducing user fees or taxes. For example, Alaska and Greenland impose per capita taxes on tourists whilst in other areas such as Svalbard environmental fees are levied to protect the environment (PFK, 2013). The municipalities currently set landing fees and competition between them for the cruise ship custom can result in negative externalities not being 
adequately considered. Establishing a concession model for access and use of Icelandic nature could also provide a framework to negotiate with the cruise ship companies.

Figure 16. Arrivals of cruise line passengers is rising

By nationality

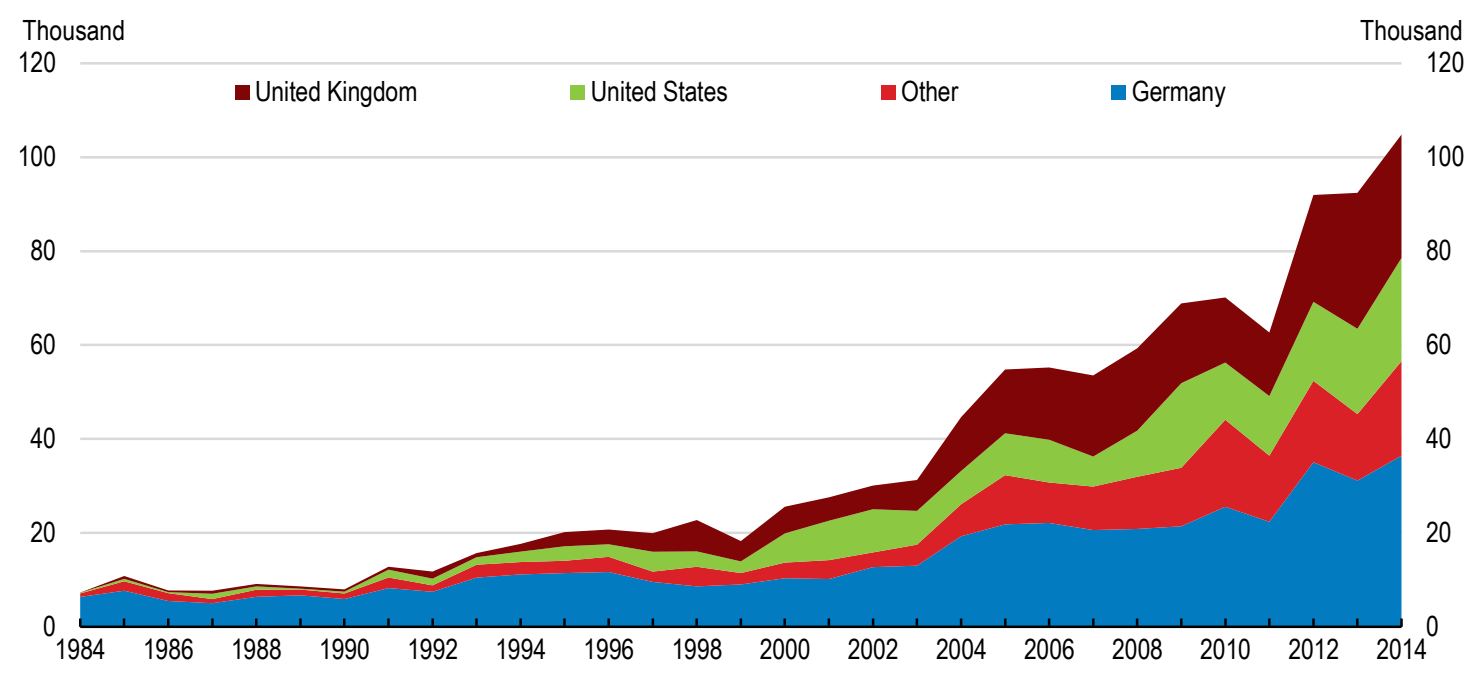

Source: Statistics Iceland.

\section{Harnessing the benefits of tourism in regional development}

The tourism sector can play a role in revitalising regional economies and support new small and medium sized enterprises, as well as encourage stewardship of the environment. While most tourism activity is concentrated around the capital region and the south, during the summer months tourists spread more evenly across the country and the aim is to develop the regional markets further. A similar effort is required to address the geographical bunching as the authorities have been pursuing to reduce the highly seasonal nature of tourism. However, implementing national tourism policies at the local level can be challenging, and municipalities lack the capacity and resources (human and financial) needed to provide the services and infrastructure required by tourists, and effectively manage tourism development at the destination level. Small municipalities in heavily visited areas face particular pressures. Municipalities need to be able to capture some of the economic value of tourism, such as receiving some of the occupancy tax, and maximise tourism's regional and local development potential, in line with a national vision for tourism in Iceland.

Destination management plans, which are already being developed in some places, can add to the policy tools for maximising the benefits from tourism while managing its environmental and social impacts. Such plans are a well-established tool to support tourism development, based on available tourism assets and taking into account local needs and characteristics. They provide a framework to guide and coordinate the actions of public and private actors to develop the critical mass of amenities and services needed to capture the economic value of tourism. They can also help promote local ownership and encourage a more integrated and balanced approach to tourism development, particularly when developed in co-ordination with the overall strategy for tourism. These plans should be developed in areas where tourism is most heavily concentrated and the impacts are greatest. Destination management organisations commonly play a central role in developing and implementing the destination management plan. Manpower and capacity is an issue for many regional tourism organisations in Iceland. Given Iceland's 
size, it may make more sense to integrate responsibility for destination management into existing regional development structures.

The regional development agency, Byggdastofnun, has supported tourism development, though largely independently from the Icelandic Tourist Board, which indirectly supports local marketing initiatives. Municipalities have developed hotels and other facilities independently, though cooperative organisations helped promote them internationally (Baum, 1999). Local government remains an important player in tourism, retaining responsibility for planning and operating many tourist attractions. The local authorities are also represented on the Tourist Site Protection Fund, which supports local government projects. Local authorities in combination with the Icelandic Regional Development Institute can undertake development projects in the tourism sector. However, tensions remain in determining funding for touristrelated infrastructure.

One interesting approach that may help develop tourism attractions around Iceland would draw on France's experience with destination contracts (OECD, 2016a). These contracts bring together public and private stakeholders with the aim of developing new tourist destinations (for example, the Louvre-Lens initiative) or ensuring the sustainability of existing destinations (as at Mont Saint Michel). Norway has introduced sustainable destination standards as a means to champion sustainability. This approach builds on a suite of indicators to assess whether tourist destinations have in place policies that are forward looking and that preserve the character and nature of the destination.

An alternative or complementary approach of defining areas to promote sustainable development has been used in a number of countries. For example, sustainable tourism development zones link tourism and land use planning and promote sustainable tourism development in a number of OECD countries (such as Chile and Mexico). Sustainable tourism development zones are clearly defined geographic areas with natural or cultural features which constitute a tourism attraction. Through the use of zoning and regulation of the activities permitted within these areas, this tool aims to promote a more integrated and balanced approach to tourism development, including controlling the environmental impact of tourism growth. These zones can be a useful instrument to co-ordinate public and private actions to develop tourism in these areas, but they also require effective and stable management over the long term.

Finally, smart specialisation may also offer a new approach. The Sustainable Arctic Tourism in Lapland, Finland is based on this model. The programme aims to develop tourism in close alignment with other sectors in the region and is based on a value chain approach. It has also involved the creation of a Tourism Safety and Security Network to develop safety plans (OECD, 2015).

\section{Mitigating the social impacts of tourism}

While tourism brings many benefits there are also concerns about some adverse social impacts. While the local population is still very supportive of tourism, survey evidence suggests it is weakening and residents in some areas are beginning to complain about tourist numbers and in some cases about migrant workers unable to speak Icelandic. Tourism is also putting a burden on health services, particularly from cruise ships, which can have many elderly passengers on board who need health interventions when they dock at various ports around the country. At present, reimbursement from insurers overseas has been partial due to difficulties in tracing some patients once they leave the country. In this context, the health authorities should strengthen systems to ensure that medical costs are reimbursed. In these areas, the authorities should consider whether payment systems can be improved, as currently reimbursement for treatment that would be expected from the agreements between countries or from insurance companies is limited. Additional demands are placed on policing and other emergency services in ensuring safety. Given the rising pressure on the rescue services, the authorities may also consider charging for their services in certain areas, as is done for mountain rescue in many alpine ski resorts. 
Over time, accommodation in private houses has been growing strongly, though it still accounts for a relatively small share of total overnight stays (Figure 17). In Reykjavik alone, a similar number of beds are estimated to be available in shared accommodation as in traditional tourism accommodation (hotels, guesthouses etc.). In part, short-term rentals blossomed through companies like Airbnb as hotel room capacity has not kept pace with demand. The flexibility of the short-term rental markets can mitigate the need to invest in hotel accommodation that may become a liability if projected tourist numbers fail to materialise, offers different tourism experiences and makes accommodation more affordable for visitors. Unfortunately, the combination of an under-supply of housing and tourist accommodation, booming house prices and rising demand from tourists and migrants is putting upward pressure on rents for long-term rentals, making housing less affordable for the young and other low-income households. In 2014, before the latest surge in house prices, low-income households were spending sizeable shares of income for renting a private apartment in comparison with the norm in the OECD but largely in line with other Nordics (Figure 18).

Figure 17. Private accommodation accounts for a rising share of overnight stays

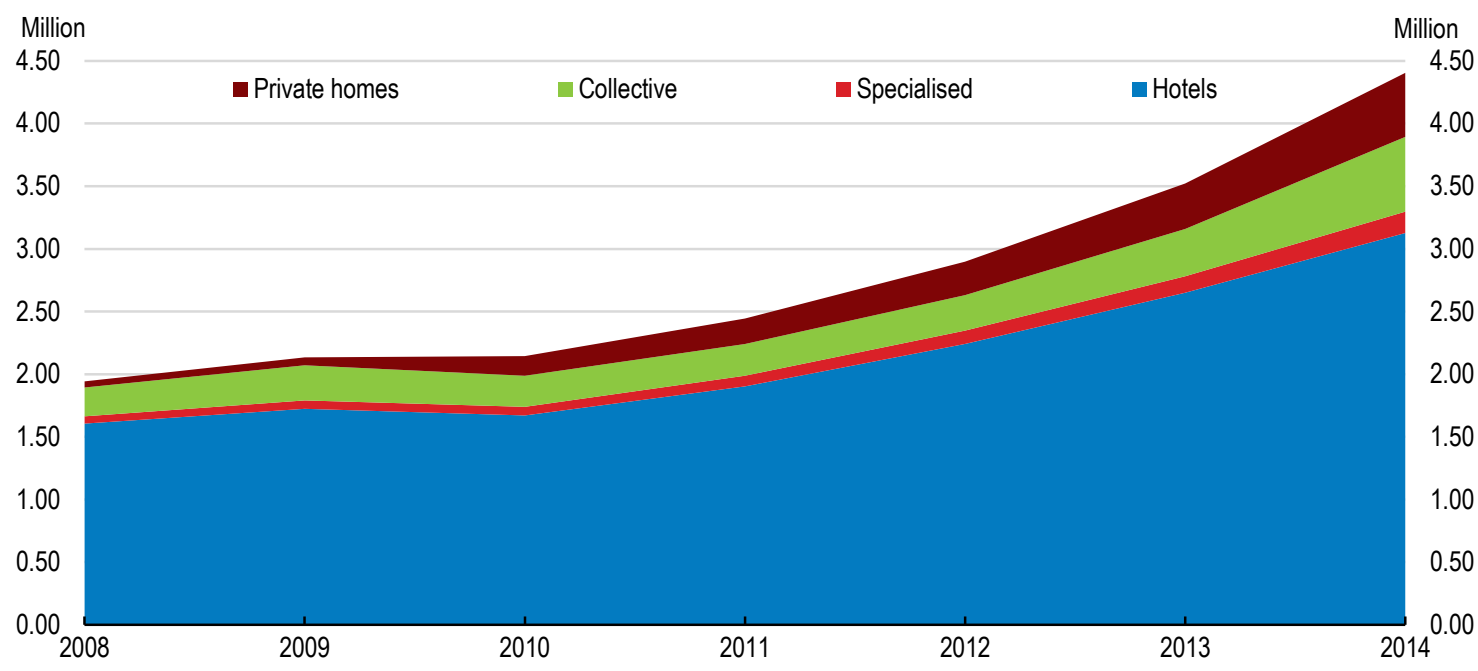

Source: OECD Tourism Statistics.

Figure 18. Rents are high

$\%$ of disposable income in the bottom quintile of the income distribution, 2014 or latest year available

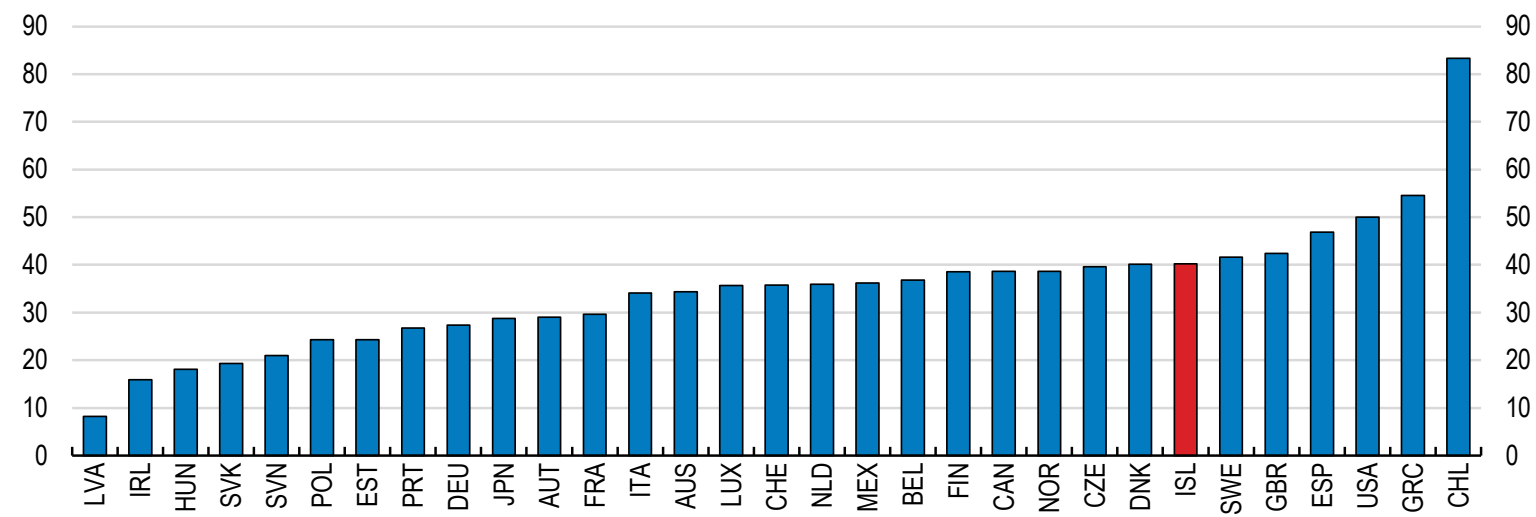

Source: OECD Affordable Housing Database. 


\section{ECO/WKP(2017)54}

The spread of the short-term rental market to meet tourist demand has changed the character of residential housing, particularly in the centre of Reykjavik. For example, some apartment blocks have switched from being residential to being given over largely to short-term holiday rentals. Many cities around the world are grappling with these issues (Box 4). Given these developments and complaints from hotels about unfair competition, the authorities introduced in 2017 a limit for Airbnb rentals for an individual renting up to 2 flats and up to 90 days per year. For rentals within these limits, the owner needs to register with the authorities. For rentals of more flats and for a longer period, the owner also needs to apply for a permit. Registrations at the beginning of 2017 have been minimal. Noncompliance risks a fine of up to 1 million króna, with enforcement the responsibility of the District Commissioner. Given that services like Airbnb are filling a gap in the market and offer flexibility, the authorities should monitor the impact of these new requirements and be ready to modify them if they choke of the competition short-term rentals create. Complaints that the playing field is not level due to tax avoidance in the sector can be countered by the tax authorities working with companies such as Airbnb so that the platforms collect and submit occupancy and other taxes directly to the tax authorities, as occurs in other countries.

\section{Box 4. Private short-term rentals and the sharing economy}

Shared accommodation, most notably through companies like Airbnb, is helping to relieve capacity constraints for a growing tourism market around the world as well as offering different visitor experiences compared to traditional tourism accommodation. Policy makers around the world are still working out how to harness the undoubted benefits from these new forms of activity. The growth of the gig economy presents challenges in how best to integrate it into existing tax and benefit systems and ensure a level playing field with other businesses without destroying the flexibility these new services offer.

In some cases, when owners make extensive use of accommodation rentals, the authorities are moving towards imposing similar standards as for the formal sector. For example, Paris requires than anyone renting out their own home for more than 4 weeks, or a property where they do no reside, must apply for a change of use and register it as a commercial property. Paris has an enforcement office that works to ensure compliance, but enforcement remains a challenge. In Dublin, a housing shortage and a shortage of hotel rooms at a time of record numbers of visitors has put upward pressure on rents. In response, the Minister for Housing created a working group to study these issues, following a ruling that offering accommodation on platforms such as Airbnb constituted a change of use and requires planning permission. Even more draconian measures are being contemplated in some cities for both hotels and private short-term rental to prevent "over tourism", as is the case in Barcelona.

In terms of levelling the playing field, Airbnb automatically collects occupancy taxes in some cities (such as Amsterdam and San Francisco) and remits these amounts directly to the tax authorities and provides information on tax compliance and statements to help providers file their income tax return (e.g. Amsterdam, Paris). Notwithstanding this co-operation, the development of the sharing economy creates considerable difficulties for both national accountants and tax authorities in measuring economic activity.

National authorities are beginning to clarify how these new activities fit into existing frameworks (OECD, 2016a). This is needed as in some cases 'new hotels' use these platforms to circumnavigate existing regulatory frameworks. In other cases, individuals renting their property occasionally may not be aware of their obligations. A fairly common approach is to establish a threshold in the extent of the activity, but monitoring compliance and enforcement remains challenging. The growth of these activities is an opportunity to review the overall regulatory framework for tourism (which can be heavy).

In part, the current pressure on housing reflects limited investment in housing following the construction crash during the crisis. Dedicated tourism accommodation and residential housing has not kept pace with demand. The economic recovery raising demand for accommodation and housing and increased immigration related to this has created additional pressure (Figure 19). As house prices are now rising strongly, residential investment is again picking up to meet the demand. In the meantime, services like Airbnb are responding to a gap in the market, as tourism growth is outstripping the construction of 
new accommodation infrastructure. The government's housing sector policy through mortgage support broke down during the crisis and is now being replaced by better targeted support for low-income households. In the wage bargaining round of 2015 the government committed to provide affordable new housing units. Laws introduced in 2016 ramped up the supply of new housing to 400 units in 2016 and reformed support through transparent housing benefits. These reforms are a welcome development in better addressing the housing needs of low-income households. Over time, as these policies begin to have an effect some of the current pressure will abate.

Figure 19. House prices are picking up and residential investment is beginning to respond

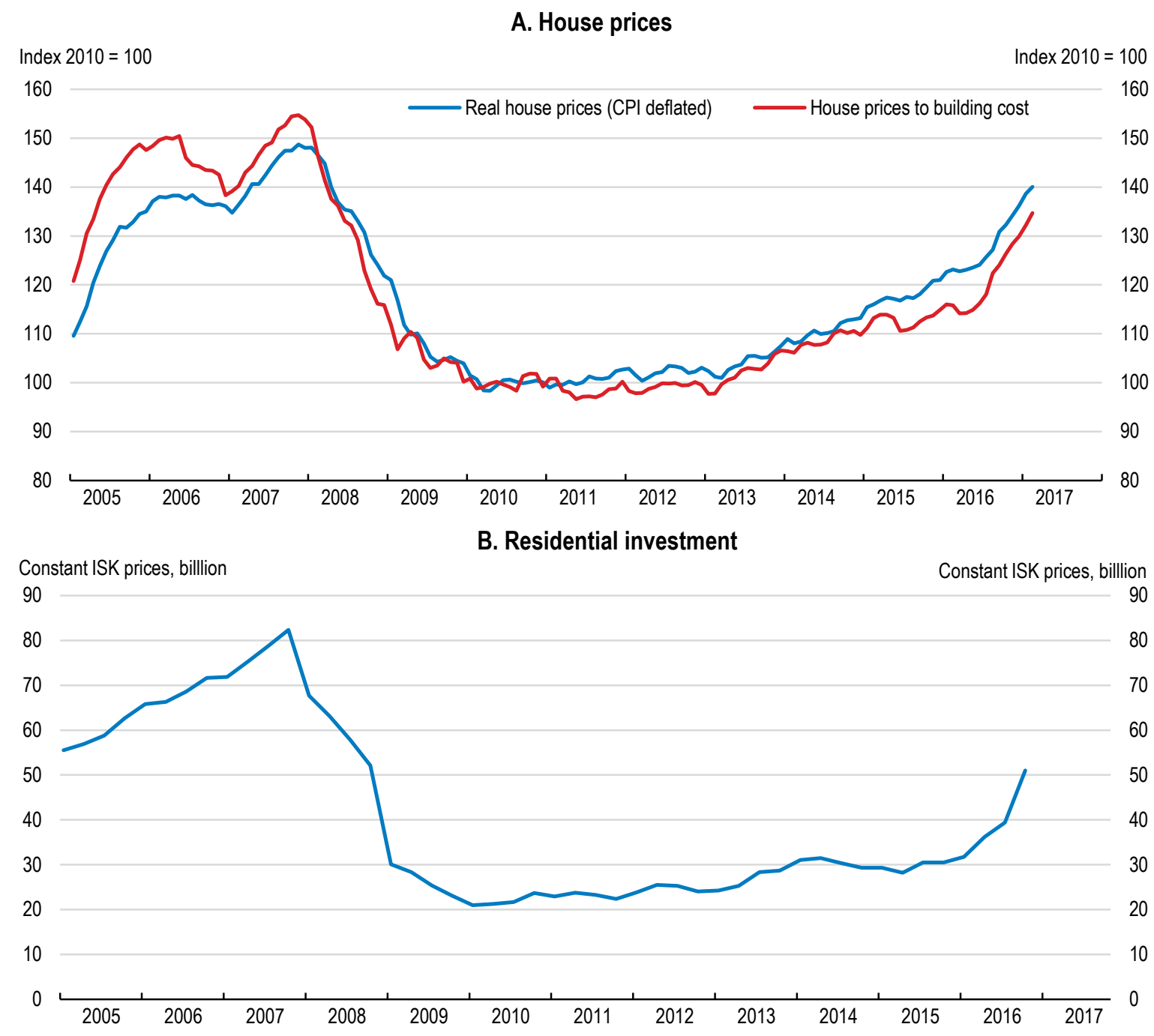

Source: Statistics Iceland, OECD Analytical Database.

\section{Boosting productivity}

A perennial challenge for Iceland has been relatively low labour productivity growth. The average annual increase in labour productivity (GDP per hour worked) for the total economy has averaged $0.4 \%$ between 2008 and 2015, which is among the lowest for the OECD countries. This occurs despite relatively 
high and rising labour quality as measured by the share of labour force having completed upper-secondary and tertiary education. Against this backdrop, the development of tourism creates challenges with the recent boom shifting resources towards what is often regarded as a low productivity growth sector.

At present, the evidence of tourism inducing Dutch disease concerns are still inconclusive although anecdotal evidence of the difficulties facing the internationally-exposed sectors suggests it may become a more pressing concern. The broad sectors where employment has been growing more strongly between 2010 and 2015 are not necessarily the sectors experiencing the largest gains in output per worker (Figure 20). In part, this reflects the economy eliminating slack on the labour market. Employment growth in sectors likely linked to tourism (such as hotels and restaurants) seems to have relatively high labour productivity growth but these flows may still drag down economy-wide productivity due to differences in productivity levels across sectors.

Figure 20. Employment growth is not strongly linked to gains in output per worker In sectors between 2010 - 2015

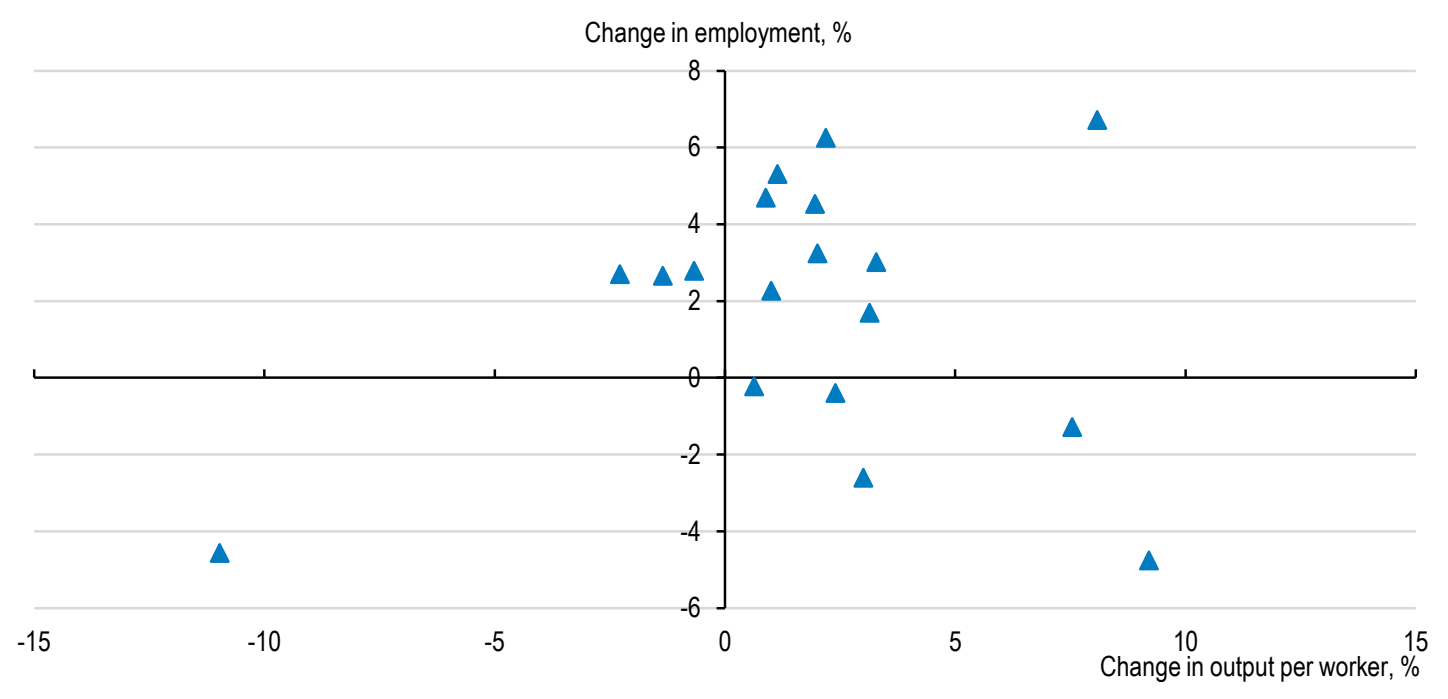

Source: Statistics Iceland.

While tourism creates opportunities for highly skilled people (such as pilots, chefs, managers and various specialist services) it also creates demand for low-skilled and often relatively low-paying jobs, such as hotel and restaurant workers, and drivers. Mismatch can emerge as tourism may not create the types of jobs that some workers want, especially the high skilled. Following the financial crisis and as tourist services began growing rapidly, the stickiness of unemployment amongst people with tertiary-level education suggests that they were initially left on the side-lines (Figure 21). In addition, the draw from tourism can potentially accentuate the problem of poor high school completion, which has been a problem during past employment booms. More students are working than around the time of the crisis, but do not appear to be dropping out of education. Partly, this may reflect greater scope for part-time employment in the sector than was the case during previous booms. Recent reforms in upper secondary education aimed at improving timely completion of studies also appear to be paying dividends in keeping pupils in school, though the evidence remains preliminary. 
Figure 21. Unemployment rates for people with tertiary education have been slower in coming down

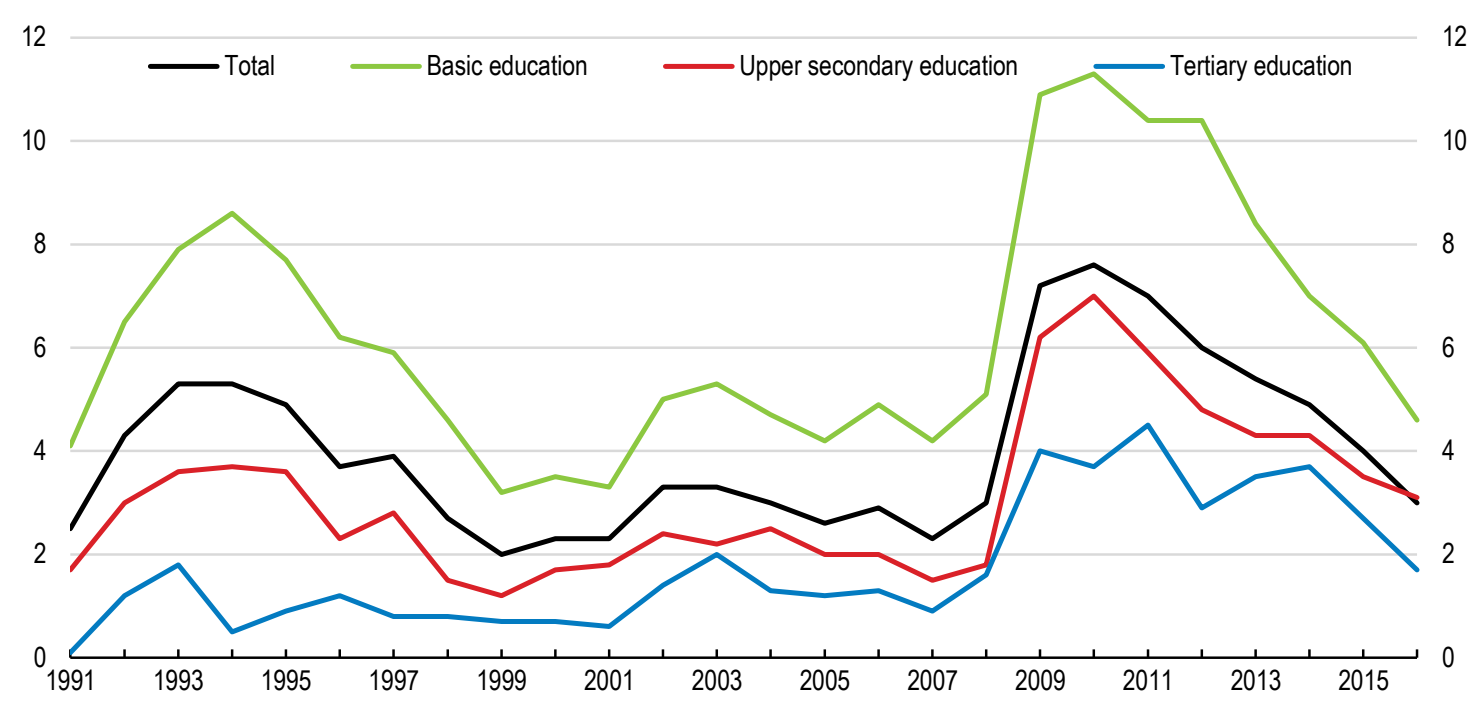

Source: Statistics Iceland.

At present, the available evidence suggests the expansion of tourism is modestly supporting wage growth. On average, wage developments have largely reflected economy-wide developments while compositional shifts in employment have had little effect on aggregate wages (Figure 22). The negative compositional impacts largely reflects developments of employment growing in lower-paid public sector and employment declining in higher-paid financial services. Large pay rises in trade and the residual "other" sector, which will include many tourism services, have on average boosted wage growth as has the flow of people into these sectors even though average wages in these sectors is only slightly above the economy-wide average. 
Figure 22. Reallocation on average has had little impact on wage gains

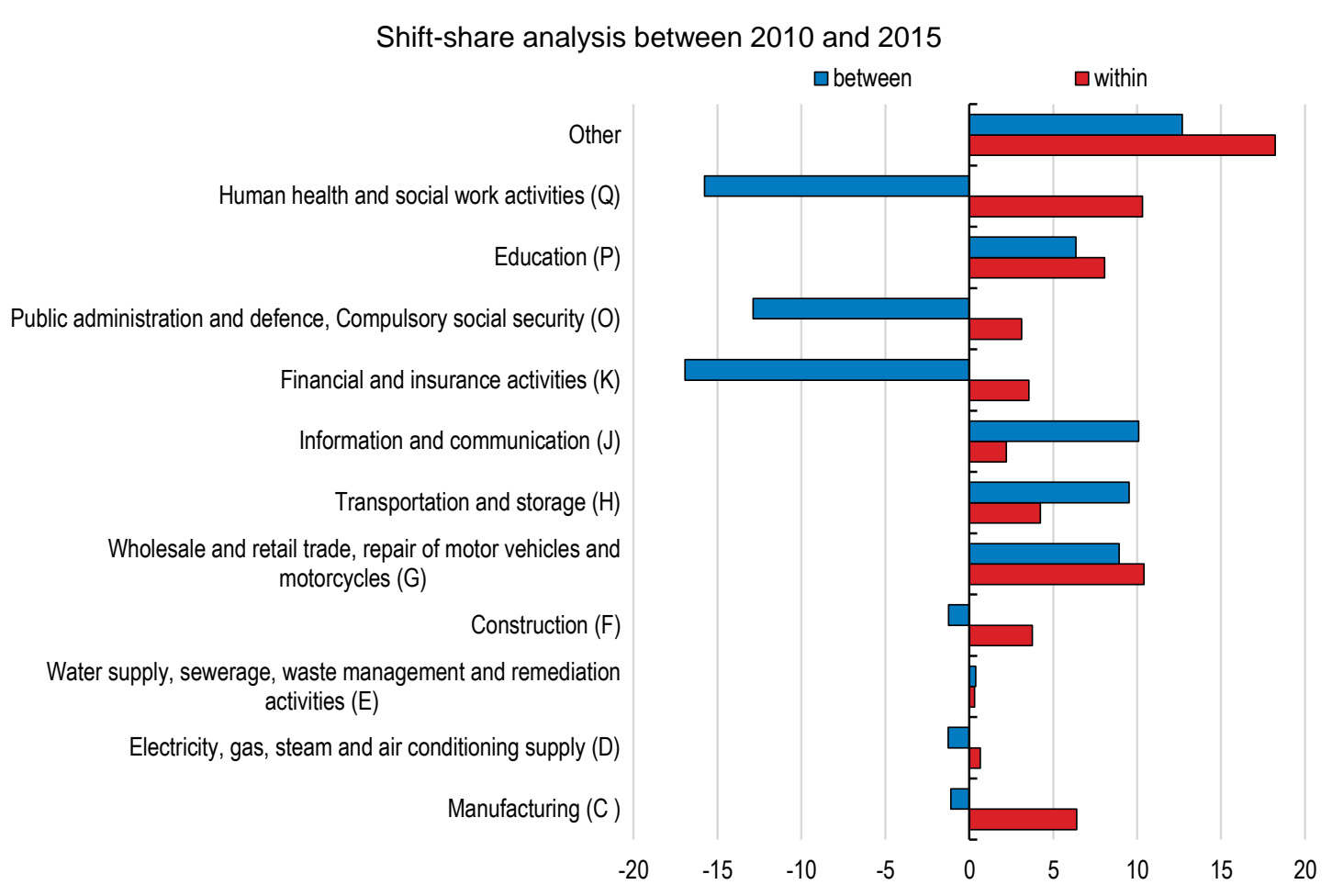

Note: the within-sector effect measures the impact of wage growth within each sector on total wage growth, assuming that labour shares are unchanged. The between-sector (shift effect) measures the impact on total economy wages assuming that the level of wages in each sector is unchanged.

Source: OECD Annual Labour Force Survey, Statistics Iceland.

Tourism need not be a low-skilled occupation and Iceland can benefit by re-orientating the development to emphasise skill acquisition. Building on nature-based tourism creates demand for qualified workers with specific skills. In addition, many of the skills required in tourism, particularly soft skills, can be transferable. The government and the tourism industry have identified skills as an issue, but there appears to be little evidence on skills gaps. To this end, identifying skills and training needs would provide the necessary information base to inform decision making on how to raise the skills of the workforce. In this context, enhancing vocational and on-the-job training would help workers gain stronger skills and facilitate future labour market mobility in the face of shifts in demand. In some cases, boosting specific tourism-related skills could start at quite early ages. Under the secondary education system in Iceland, municipal authorities have significant flexibility to orient the curriculum, suggesting potential to inject Tourism Awareness and other specific programmes in areas where tourism is an important part of the economy, or to respond to specific local skills needs.

One specific area where training could be boosted is in ensuring workers in the tourism sector help tourists remain safe. Iceland has a unique natural environment and tourists unused to the conditions are often unaware of the risks they can run, particularly during the winter months. This has contributed to a number of deaths over recent years. More extreme events, such as glacial floods - of which tourists appear to be largely unaware - could lead to considerable loss of life (Bird et al. 2010). In this light, existing training in some sectors (e.g. tourism services and nature management) may need to be strengthened to ensure that tourists understand the risks and how they can be mitigated. 
ECO/WKP(2017)54

\section{Harnessing a dynamic business sector}

A dynamic competitive business sector will support productivity growth and help offset Dutch diesase type pressures. The Icelandic government has been working to simplify the legislative framework for businesses in the tourism sector. To harness the full extent of business creation, the government should review the number of licences and permits required and simplify regulations as well as the administrative burden on establishing a business. For example, the inspection regime for new businesses can be onerous. While overall, the regulatory environment in Iceland is comparatively business friendly, a number of barriers to entry can thwart new business creation. The OECD measure of product market regulation suggests that further progress can be made in reviewing the legal barriers to entry in air transport and airports and seaports.

When confronting concerns about productivity growth, keeping momentum in pursuing a productivity enhancing agenda, such as initiated by the Growth Forum - a group which brings together politicians, social partners and academics - acquires some importance. The government has been working to implement recommendations prepared by the Growth Forum mainly by targeting improving efficiency in the public sector. As this programme develops it would be advisable to develop thinking on how best to support private sector productivity growth opportunities. In some cases, public policies that help the tourism sector integrate with the global tourism market effectively may be helpful, as small firms often lack the resources to overcome information barriers.

As discussed in the previous Economic Survey (OECD, 2015), ensuring robust competition can be challenging in a small economy, but progress in removing unwarranted regulatory and administrative barriers to entry can encourage more entry to the benefit of consumers. To an extent, the development of more competition emerging between airlines has spurred tourist development. Earlier complaints that the low-cost carrier Wow Air could not obtain slots at Keflavik airport to compete in the market for international transfers with Icelandair was a concern, with the slot-allocation mechanism in place being recognised as detrimental to competition as early as 2008. The situation today with many more carriers entering the market has increased competition in the sector, driven down prices and created new travel opportunities. The slot-allocation mechanism remains in place, however, and affects the OECD's Services Trade Restrictiveness Index. In this light, reviewing how slots are allocated and traded is warranted.

Competition policy can play a role in supporting productivity growth, notwithstanding the challenges of promoting competition in a very small open economy. In Iceland, competition in domestic services can be weak, often through artificial barriers to entry, allowing some companies to earn large rents. In this connection, as with new forms of economic activity in the sharing or gig economy, competition policy may need to support the entry of new firms into the market. In particular, temptation to shore up existing firms, which are currently suffering from the appreciation of the króna, should be resisted. Such measures can dissipate competitive pressures and the need to keep moving towards the productivity frontier. Effective competition policy can potentially spur productivity by promoting reallocation of resources and creating conditions conducive to new entry and innovation. Indeed, OECD work suggests that policies hindering market exit can impact negatively on productivity (Adalet McGowan et al., 2017). Against this background, the competition authorities should consider using the OECD's Competition Assessment Toolkit to ensure that policy objectives are being achieved without undermining competitive pressures.

\section{The policy framework has been evolving}

The government has been very successful in promoting Iceland as a tourist destination, with the Ministry of Foreign Affairs responsible for promoting tourism internationally. Promote Iceland and its Inspired by Iceland campaign - both public-private partnerships which have been supported by the Ministry for Tourism, Innovation and Industry - have been successful in putting Iceland on the tourism 


\section{ECO/WKP(2017)54}

map. The rest of the policy framework is still developing and when in place will grant the government greater ability to manage its further development, including using advertising more strategically to cement the tourism branding Iceland wants to pursue. At present, tourism lacks the robust institutional structures which exist in other sectors, notably the fishing sector. A stronger institutional framework at national and sub-national level is required to manage the development of tourism and ensure a coherent approach to different policy dimensions (land use, housing, labour, education and especially transport). Furthermore, the very information needed to inform decisions is sometimes lacking (Box 5). Progress on these fronts will help guarantee that Iceland can optimise the value generated by the sector. An OECD Tourism Policy Review of Iceland would offer guidance in making progress on these issues.

\section{Box 5. Statistics and research to support decision making}

A strong evidence base is essential to guide policy development. Statistics Iceland produces Tourism Satellite Account to the national accounts, but these data are not very timely. In a rapidly evolving environment more up-to-date information is needed. In addition, the tourism satellite accounts do not incorporate the environmental dimension and other externalities of tourism development, which policymakers need to take into account. As mentioned above, even established statistics face difficulties in capturing the new sharing economy. Iceland is introducing a new Border Survey which will help address some data gaps and be available more quickly. The use of credit card data (such as in New Zealand) and other real-time data sources can also provide partial snapshots of developments to complement the information on retail spending that Iceland already uses.

The development of a few well targeted sustainable tourism indicators will be important for Iceland to measure, monitor and manage tourism flows. A number of countries have been active in developing such statistics to enhance the sustainability and inclusiveness of tourism. Slovenia has recently piloted sustainability indicators to support its positioning as a 'green' destination, while the new EU Tourism Indicators System creates a toolkit for sustainable destination management. Finland has developed a system for measuring and reporting the socio-economic benefits of recreation and tourism in protected areas (OECD, 2016b).

Beefing up the scientific advice, including establishing carrying capacity of the most sensitive natural environment has been advocated for some time (Gunnarsson and Gunnarsson, 2002). At the moment there is little co-ordinated research. Supporting research would build the evidence base to support decision making and help ensure Iceland maximises the benefits of tourism.

In 2011, the Icelandic government developed "Iceland Tourism Strategy 2011-2020". The strategy drew on the OECD's Green Growth Strategy and a parliamentary initiative to strengthen the Green Economy in Iceland. Green considerations are thus at the heart of the national strategy. Around 50 actions were identified by the parliamentary group spanning the introduction of sustainable development in regional development plans to developing methods to green Icelandic businesses. Building on these considerations, the strategy aimed to: maintain Iceland's unique nature with focused and strong emphasis on strengthening destination; improve the quality, professionalism and environmental consciousness of the tourism industry; promote increased profitability and respect for the industry; extend the tourist season; reduce seasonal fluctuations, and; promote better distribution of tourists around the country.

The governance of tourism remains spread across a number of bodies (OECD, 2016a). From 2012, the responsibility for tourism has mainly rested with the Ministry of Industry and Innovation, with the Icelandic Tourism Board responsible for implementation. The main tasks include:

- Licensing and administration, including issuing licences, registration and monitoring

- Environmental affairs, including implementing a tourism strategy, co-ordinating environmental and educational affairs, disseminating information, collaborating internationally and supporting local and regional development, 
- Quality, including implementing the quality and environmental assurance scheme (VAKINN), and collecting data on tourism.

The initial approach to developing tourism was superseded by events, with tourist numbers far outpacing expectations. In reaction, the Ministry of Industries and Innovation in 2015 launched a Road Map for Tourism. A number of weaknesses in the previous policy framework were identified, including uncertainty about responsibilities and the organisation of the sector, a complex legal framework and poor data. The Road Map aims to address these weaknesses and support sustainable development. One of the main thrusts of work until 2020 will be co-ordinating management of tourism. Other targets include ensuring positive visitor experiences, improving data reliability and comparability, promoting nature conservation, improving skills and quality, increasing profitability and distributing tourists around the country more. The Roadmap is a step in the right direction, but needs to be more strategic in its approach, prioritising actions, setting clear targets, and outlining an action plan to achieve these goals. It also needs to be supported at the highest level, with sufficient resources to support implementation.

The experiences of other countries could help in setting more strategic goals. One innovation in Ireland's Growing Tourism to 2025 has been a shift from setting visitor targets to prioritising revenue, while protecting natural and cultural assets (Department of Transport, Tourism and Sport, 2015). New Zealand has moved towards promoting itself as an adventure tourism destination. A Green Growth Advisory Committee also recommended moving towards high value tourism in a greener market segment (OECD, 2015). Costa Rica has long positioned itself as an eco-tourism destination and has taken proactive measures to protect its environment while promoting environmentally-friendly forms of tourism. It also promotes adventure and beach tourism, and is looking to further diversify this offer without undermining its environmental reputation. These examples may provide a useful framework for Iceland to build on in the further elaboration of its own tourism policy objectives.

The main concrete step to implement the Road Map in Iceland was the creation of a Tourism Task Force, which brings together the Minister for Industries and Innovation (who chairs the Task Force), the Minister of Finance, the Minister of Environment and Natural Resources, the Minister of the Interior and representatives from the Icelandic Travel Industry Association and the Icelandic Association of Local Authorities. As such, the Task Force brings together the major players involved and can provide the basis to overcome fragmentation in decision making. However, its ability to influence policy and its financing is limited. For example, the Taskforce has proposed a tourism education and training programme, with funding limited thus far to a one-year preparatory period. Furthermore, the Taskforce, which is due to wind down in 2020, does not provide a sufficient framework for inter-ministerial co-ordination, which could be more formalised.

Approaches adopted by other countries to strengthen tourism policy include establishing an interministerial committee or working group. This could be a permanent body addressing priority issues, as is the case in Mexico, the United Kingdom and the United States. The experience of the Tourism Cabinet in Mexico shows how such inter-ministerial groups can provide strategic focus, as well as the benefit from prioritising core areas (OECD, 2017). In other countries, such as New Zealand, the inter-ministerial group is brought together as needed on an issue-by-issue basis. As tourism's impact cuts across different policy domains a whole-of-government approach helps build coherence and policy consistency (OECD, 2015). Lack of co-ordination has contributed to some of the problems experienced during the breakneck pace of tourism growth. In this context, when the different actors are brought together policymaking can exploit the linkages as well as manage the externalities across the economy and different policy objectives (OECD, 2015).

An inter-ministerial group focussing on tourism - such as the current co-ordination group chaired by the Prime Minister's office - would have the necessary power to address the most urgent need for 


\section{ECO/WKP(2017)54}

investment at congested and heavily visited sites and to fund basic infrastructure development to protect the environment. Investment is also needed in the wider infrastructure network, particularly roads. In many cases the investment needs are understood and the amounts relatively small. However, the current framework for determining investment has faced difficulties. At present, funding is available from the Tourism Site Protection Fund, which is partly financed by the occupancy tax. However, the criteria governing this scheme have limited its use, in particular the requirement for applicants (landowners, municipalities) to provide $20 \%$ of project costs upfront. The Fund also does not seek to manage or direct tourist flows, or to optimise investment as part of a co-ordinated approach to infrastructure development. A new infrastructure plan for nature and tourism sites, looking at a 12 year time horizon with shorter 3 year rolling investment plans, may go some way in addressing this. However, funding has not yet been allocated to the plan and it remains to be seen how it will function alongside the Tourism Site Protection Fund.

\section{Ensuring consistency in tourism and transport policy}

The consistency of transport and tourism policy appears weak. Transport is not addressed in the Roadmap, though partly mitigating this lacuna, the Interior Ministry - which is responsible for transport does sit on the board of the Taskforce. This gap represents an area for improvement as coherent transport and tourism policies can help manage visitor flows. Transport can play an important role in shaping a more sustainable approach to tourism development in Iceland.

Expanded air access and traffic through Keflavik has been a key facilitator of tourism growth in recent years, delivering higher volumes of visitors. The expansion of passenger transport operations through Keflavik airport has taken place with little discussion with tourism policy makers, and apparently in the absence of a national aviation plan, despite the importance of the airport as a connectivity hub for the economy as a whole. In contrast, in cities like Copenhagen, a strategic approach to route development has been based on a national aviation plan, which may target identified routes. In the case of Iceland, an expansion plan increasing capacity at Keflavik airport has been developed by the state-owned company that operates the airport. The impact on tourism flows needs to be considered in the government's decision on this plan, and should be informed by an assessment of the likely impact the increase in capacity will have on flows into the country. Even without further expansion, the current facility still has capacity outside of the peak times demanded by the airlines.

Decision making should also rely more heavily on cost-benefit analysis than has been the case hitherto. Major infrastructure decisions in particular need to be based on sound and wide-ranging analysis. The development of the air transport infrastructure and Keflavik airport in particular should take into account not only the economic effects but also the environmental and social impacts of different development options.

Of total arrivals, at present one half are transfer passengers, spending only a little time at Keflavik before flying on to another destination. The development of a hub-and-spoke strategy has been successful and allowed the number of connecting airports to increase to around 80 today from under 50 in 2009. The number of carriers has increased from 7 to 25 . The airport operator, Isavia, along .with tourist service companies have promoted flights during off peak hours and the low (winter) season with some success. Notably visitors from some countries, such as the United Kingdom, now arrive more frequently in the winter months, whereas they previously visited primarily during the summer months.

Some money is being invested to promote international airports in other parts of the country, in part to relieve the tourist pressure on the regions closest to Keflavik airport. A route development fund provides subsidies to promote direct access and encourage airlines to offer direct international flights to other airports in the country. The fund has generated little interest from airlines (only 1 grant so far), indicating that such routes may not be commercially interesting (although several international charter flights do 
operate to Akureyri). The experience from other countries, such as Mexico, that have attempted to develop international point-to-point airline routes has not always been successful (OECD, 2017).

Marketing support is one strategy to stimulate a higher and sustainable level of demand on a route than may not be commercially viable or interesting. Other strategies such as providing financial incentives to carriers have shown more problematic results, with airlines often suspending services once funding has ended. At a minimum, a policy to stimulate growth in air transport connectivity should: have clear and transparent guidelines, be open and accessible to all carriers, demonstrate measurable results to show value for taxpayer money, aim to develop the long term tourism market rather than simply provide funds for immediate route start-up, and be structured in a way that reduces public contributions over time as the service becomes financially viable.

Encouraging direct flights will likely be difficult and a hub and spoke arrangement may work better, particularly if large numbers of the passengers passing through Keflavik also want to stopover. The government currently subsidises the operation of the regional airports (they cover only a share of operating costs). In this light, both as owner of the airport operator and route subsidiser the government can direct the development of the domestic airline market. However that configuration would put Reykjavik airport under pressure as there is political support to maintain an airport servicing domestic flights in the centre of the capital, including for regional access to medical treatment. On the other hand, Reykjavik airport occupies a significant space near the centre of the city, which the city authorities could develop thereby easing pressure on the Reykjavik housing market. In this light, cost-benefit analysis of the different options for developing the airport sector, taking into account the environmental and social benefits and externalities, would help better inform decision making.

The growing number of tourists also creates challenges for the transport infrastructure within the country. The transport system plays an important role in how a destination physically develops, and significantly influences visitor mobility. The transport network also influences the potential to connect visitors with other parts of the country and open up new destinations. From a tourist's perspective, the current bus system connecting visitors with hotels in downtown Reykjavik is efficient and works well, in the absence of a competitive taxi service. However, this model serves to automatically funnel all visitors through Reykjavik, with the exception of those joining organised tours on arrival, or renting a car. The road infrastructure along the Golden Circle is also under pressure.

Finally, the development of the main airport at Keflavik has a strong local impact. In 2015, investment picked up considerably (almost doubling) in line with development plans to 2040. While the new investment will allow the share of transit passengers to increase as a share of all passengers, increased capacity will possibly further intensify tourism's pressure on surrounding regions. On the other hand, airport and airline-related jobs already account for an important share of total employment, at around 3\% in 2016. In the coming years as the airport is set to expand, job creation will continue at a steady clip.

\section{Setting the path forward}

The natural environment presents a key asset on which to develop a unique nature-based tourism sector. The pristine natural environment, specific biodiversity and the gradual increase in recognised World Heritage Sites coupled with the extensive use of geothermal energy burnishes its green credentials. However, to achieve its full potential, Iceland needs to protect these natural assets and develop policies ensuring sustainable and inclusive tourism. One approach could be to model management of the sector on the fisheries sector, where scientific advice from the Marine Research Institute has provided an invaluable guide to ensuring the preservation of fish stocks. The difference between maximum yield and maximum sustainable yield can serve as a useful benchmark for tourism policy. 


\section{ECO/WKP(2017)54}

In setting the path forward, important decisions are needed regarding the most appropriate model of tourism development for Iceland. Current growth rates in tourist numbers are neither sustainable nor desirable in the longer term and the focus needs to concentrate on total social value. This requires policymakers and industry participants to consider where Iceland would like to be positioned in the global tourism market, the type of tourism they country wants to develop, and how best to manage this process and maximise the return from Iceland's natural wealth while also protecting it for current and future generations. This will necessarily involve some consideration of the number of visitors the country can sustainably absorb from both an environmental and social perspective and the associated infrastructure requirements. Given these choices appropriate governance arrangements and policies to achieve these goals will need to be established. 


\section{Box 6. Recommendations}

Main recommendations

- Establish an inter-ministerial tourism strategy focused on making tourism environmentally, socially and economically sustainable. This should include non-government stakeholders.

- $\quad$ Remove current tax subsidies for tourism-related activities, by taxing them at the standard VAT rate and broadening the base to excluded services.

- $\quad$ Limit the number of visitors to fragile sites.

- Introduce user fees to manage congestion and pressure on the environment.

- Subject infrastructure investment to cost-benefit analysis, including consideration of social and environmental impacts.

- $\quad$ Ensure transport and tourism policy are consistent.

- Improve the economic analysis of tourism activity, with better data and research.

- Use vocational and on-the-job training to build skills in the tourism workforce.

Other recommendations

- Elaborate a long-term strategic plan for tourism with intermediate steps.

- Preserve areas of natural wilderness, limiting man-made structures and keeping numbers to carrying capacity.

- Improve communication with tourists about country specific natural risks and what to do in case of extreme events.

- $\quad$ Conduct an OECD Tourism Policy Review of Iceland.

- Review regulatory barriers to entry and exit in key sectors, using the OECD Competition Assessment Toolkit. 


\section{REFERENCES}

Adalet McGowan, M, D. Andrews and V. Millot (2017), "The Walking Dead?: Zombie Firms and Productivity Performance in OECD Countries", OECD Economics Department Working Paper, No. 1372

Baum, T. (1999), "The Decline of the Traditional North Atlantic Fisheries and Tourism's Responses: The Cases of Iceland and Newfoundland", Current Issues in Tourism, Vol. 2, No. 1, pp. 47-67.

Bird, D., G. Gisladottir and D. Dominey-Howes (2010), "Volcanic Risk and Tourism in Southern Iceland: Implications for Hazard, Risk and Emergency Response Education and Training", Journal of Vulcanology and Geothermal Research, Vol. 189, pp. 33-48.

Central Bank of Iceland (2017), Monetary Bulletin, 2017.1, Reykjavik

Daubanes, J. (2017), "Sustainable Management of a Productive Natural Capital", OECD Economics Department Working Paper [Forthcoming].

Department of Transport, Tourism and Sport (2015), People, Place and Policy: Growing Tourism to 2025, Dublin.

Ferdamalastofa (2016a), Tourism in Iceland in Figures: May 2016, Reykjavik

Ferdamalastofa (2016b), International Visitors in Iceland: Summer 2016, Reykjavik

Karlsson, L. and S. Dolnicar (2016), "Does Eco Certification Sell Tourism Services? Evidence from a Quasi-experimental Observation Study in Iceland", Journal of Sustainable Tourism, Vol. 24, No. 5 , pp. 694-714.

Gunnarsson, B. and M-V. Gunnarsson, (2002), "Iceland's Central Highlands: Nature Conservation, Ecotourism, and Energy Resource Utilization", USDA Forest Service Proceedings, RMS-PP26, pp. 54-63.

Haxton, P. (2015), “A Review of Effective Policies for Tourism Growth", OECD Tourism Papers, 2015/01, OECD Publishing, Paris.

Holzner, M. (2011), "Tourism and Economic Development: the Beach Disease?", Tourism Management, Vol. 32,pp. 923-933.

IUCN (2014), Tourism and Visitor Management in Protected Areas, International Union for Conservation of Nature,.

McKinsey (2012). Charting a Growth Path for Iceland. McKinsey and Company.

OECD (2014), Environmental Performance Review: Iceland 2014, OECD Publishing Paris.

OECD (2015), OECD Economic Surveys: Iceland 2015, OECD Publishing Paris.

OECD (2016a), OECD Tourism Trends and Policies 2016, OECD Publishing Paris. 
OECD (2016b), “An OECD Review of Statistical Initiatives Measuring Tourism at Subnational Level”, OECD Tourism Papers, 2016/1, OECD Publishing Paris.

OECD (2017), Tourism Policy Review of Mexico, OECD Publishing Paris.

Olafsdottir, R. and M. Runnstrom (2011), "How Wild Is Iceland? Wilderness Quality with Respect to Nature-based Tourism", Tourism Geographies, Vol. 13, No. 2, pp. 280-298.

PKF (2013), Promote Iceland: Long-term Strategy for the Icelandic Tourism Industry, PKF Accountants \& Business Advisers.

Saethorsdottir, A (2010), "Planning Nature Tourism in Iceland based on Tourist Attitudes", Tourism Geographies, Vol. 12, No. 1, pp. 25-52.

Saethorsdottir, A. and J. Saarinen (2016), "Challenges due to Changing Ideas of Natural Resources: Tourism and Power Plant Development in the Icelandic Wilderness", Polar Record, Vol. 52, No. 262, pp. 82-91.

World Economic Forum (2015), Travel and Tourism Competitiveness Report 2015,

WTO (2011), Tourism Towards 2030, World Tourism Organisation, Madrid.

WTTC (2016), Travel and Tourism Economic Impact 2016: Iceland, World Travel \& Tourism Council 